\title{
NEW LANGUAGE FOR A NEW COMEDY: A LINGUISTIC APPROACH TO ARISTOPHANES' PLUTUS
}

\section{Introduction}

Aristophanes' Plutus is often regarded as a dull play. According to two of the leading specialists on Aristophanes in Great Britain, the comedy displays 'a certain amount of disjointedness in its moral and religious themes, and a certain lack of energy in its humour', 1 and the modern reader feels a 'decline in freshness, in verbal agility, in sparkle of wit, in theatrical inventiveness'. ${ }^{2}$ Others regret alleged or real inconsistencies, ${ }^{3}$ the lack of punning and verbal play, ${ }^{4}$ the absence of nearly all choral interludes, a parabasis, and political advice in general, ${ }^{5}$ and the dearth of references to historical figures. ${ }^{6}$ Thus, the temptation is strong to follow those who read a medical history into Plutus: Aristophanes, by now sixty-five years old, had grown tired and saved his esprit for every third or fourth play. ${ }^{7}$ But such speculations do not do justice to a poet who did not have to write for a living. Before accepting them, we should first try to explain the change in other ways, admitting that Plutus may differ from the earlier plays for generic reasons. On this path, the linguistic analysis of Plutus will turn out to be helpful.

\footnotetext{
MacDowell (1995) 349.

2 Sommerstein (1984) 314: cf. Sommerstein (2001) 25.

3 Cf. e.g. the assumption that Plutus used to visit only the wicked because he was blind. Despite what is often maintained (e.g. Dover (1972) 204, Konstan (1995) 85 and 89, and Lévy (1997) 208-11), the ideas that wealth is distributed equally and that only the good will become wealthy are not contradictory: as soon as only the good become rich, everyone - including the impoverished sycophant (Plut. 850-3 and

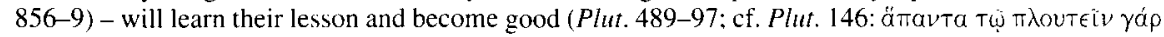
Ė $\sigma \theta^{\prime}$ iाtík

+ Cf. Newiger (1957) 162 on the loss of comic imagery.

5 This holds true even if one adopts the 'ironic' reading favoured by German scholarship, according to which Aristophanes would want to show that the new order cannot work (see Süss (1954) 311-13. Newiger (1957) 173-8. Hertel (1969) 27-8. Gelzer (1970) 1508-9, Flashar (1975) 411-30; cf. also Heberlein (1980) and (1981) and in English scholarship Bowie (1993) 284-91). Note, however, that the

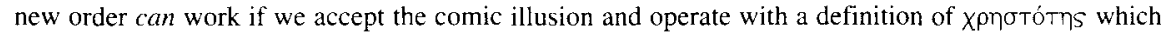
includes the requirement of an adequate personal contribution to national economy. Also, "if Aristophanes had wanted his audience to think that Poverty was right, he would have had to show Khremylos' plan failing in the end' (MacDowell (1995) 346).

6 Or to historical events and the current war (the most prominent exceptions being Plut. 665-6 and 716-25: cf. further Plut. 170-80, 550); for a discussion see Dillon (1987) 166-73.

7 Cf. MacDowell (1995) 327 and Sommerstein (2001) 25. The fact that Aristophanes wrote much less in the second half of his career (Sommerstein (1984) 314) shows that he did not feel obliged to produce new plays every year. Holzinger (1940) 309 detects the signs of a decline in certain phrasal repetitions (Plut. $968 / 1113 / 1173,138 / 1115$, but not $1060 / 1066$ and $862 / 957$ which he regards as motivated).
} 
My present aim is to show that Plutus becomes, contrary to the opinions just cited, a most fascinating play once it is read from a linguistic perspective.

In order to make such a point, a certain amount of linguistic detail, including statistics, is necessary. However, it is hoped that not only 'pure' linguists will find something useful in the following observations. They are meant to support a much more general thesis: that the formal analysis of an ancient drama can open up new perspectives on cultural, social, and literary phenomena.

A grand claim like this must of course be substantiated. Hence, I will have to deal with a series of very concrete issues. First and foremost, the linguistic relationship between Aristophanes' Plutus and his earlier comedies must be assessed: are they similar or are they different, is there a new language for a new comedy? And if Plutus is different, does this difference go beyond what one could reasonably expect from Aristophanes' latest surviving comedy, of $388 \mathrm{BC}$, staged nearly forty years after his first play? Second, since I will in fact argue that the language of Plutus contains various 'new' features, ${ }^{8}$ I will also have to ask how each of them is best accounted for, either on the literary level or from a sociocultural and linguistic point of view. And third, an attempt will be made to shed some light on the most fundamental mystery: why is Plutus different?

The basis needed to deal successfully with this agenda is a careful linguistic reading of Plutus. The major part of this paper therefore consists of a catalogue of linguistic phenomena. It may seem a desperate enterprise to fight against the stigma of a dull comedy by presenting a list whose dullness must be, if anything, worse than that of the raw material it contains. On the other hand, such an approach promises greater structural clarity than could be achieved by other arrangements. For reasons of space, I will have to content myself with few and brief quotations from Plutus itself, but the references (mostly banished to some bulky footnotes) should be exhaustive and make the parallel consultation of the Aristophanic text easy. ${ }^{9}$

\section{The language of Plutus: a review}

The most systematic way of discussing what one may call the irregular or 'unAristophanic' elements in the language of Plutus is a review arranged by categories such as 'phonology', 'pragmatics', 'lexicon', etc. We will start with the areas of phonology and word formation because they are quickest to deal with.

* A first brief and unsystematic list of linguistic peculiarities in Plutus was compiled by van Leeuwen (1904) xix-xx. Unlike van Leeuwen. I will consider not only what is exclusive to Plutus (or Plutus and Ecclesiazusae) but also what is uncommonly frequent (or rare) in Plutus as compared with Aristophanes' other comedies.

9 The translations from Aristophanes are taken from, or based upon, Sommerstein's Warminster editions (esp. Sommerstein (2001) for Plutus). 


\subsection{Phonology}

Phonological changes take some time to become established since phonetic modifications do not affect the phonological system of a language from one day to the next. Moreover, wherever there is a standardised orthography of some sort, texts written according to the rules do not usually represent spoken reality faithfully. Greek iotacism is a case in point: in Attica its beginnings can be traced back to the fifth century $\mathrm{BC},{ }^{10}$ but it is not acknowledged in Greek orthography even today. If Aristophanes' actors by the time of Plutus should have pronounced a word like "̈ $\chi \in \mathrm{V}$ with a more closed second vowel than at the time of Acharnians, Aristophanes would still have written $\epsilon \chi \in \nu$ or $\epsilon \chi \epsilon \backslash \nu$ rather than $\epsilon \chi\lfloor\nu$.

Nevertheless, there may be one phonological 'lateness signal' in our text. Plut. 166

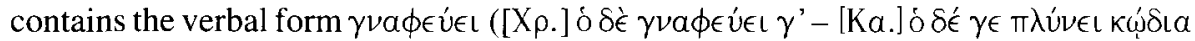
'[Chr.] Another is a fuller - [Ca.] And another washes fleeces'). This is the standard orthography in later Greek, ${ }^{11}$ whereas the literary ${ }^{12}$ and epigraphic ${ }^{13}$ evidence for

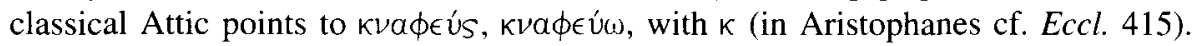
Surprisingly, the variant spelling with $\gamma$ also occurs in Wasps, staged in 422 BC (Vesp. 1128).

Now one might object that the manuscript tradition counts for nothing in such a case. That is true for the line in Wasps, ${ }^{14}$ but not for that in Plutus. Whereas $\gamma \nu$ is a "heavy cluster' of stop + liquid, where the usual muta-cum-liquida rule that a preceding shortvowel syllable remains short does not hold, the cluster $\kappa \nu$ is light. ${ }^{15} \mathrm{~A}$ short-vowel syllable before $\kappa \nu$ therefore counts as a short, but a short-vowel syllable before $\gamma \nu$ counts as long. The situation in Wasps is ambiguous: a long vowel precedes the cluster and $\kappa \nu$ could be written or pronounced without difficulty. ${ }^{16}$ In Plutus, on the other hand, the preceding word is $\delta \dot{\epsilon}$, placed in arsi. ${ }^{17}$ Thus, the reading $\gamma v a \phi \in \dot{U} \epsilon t$ is correct and the phonological change is guaranteed. ${ }^{18}$ Since the change did not affect all the words with $\kappa \nu$ anlaut, this may be evidence for a popular or 'low' pronunciation of a word designating a popular or 'low' profession. ${ }^{19}$ Possibly foreign influence also played a

in Cf. Duhoux (1987) and Teodorsson (1987).

11 Cf. Mayser-Schmoll (1970) 155 and Gignac (1976) 77-8 for the Ptolemaic and Roman papyri respectively.

12. As implied by the scholiast on Plut. 166 who argues that $\kappa \nu$-exceptionally forms position here: cf. below.

13 The change to $\gamma \nu$-is first attested in $401 / 400 \mathrm{BC}$, but the evidence is limited to five attestations of

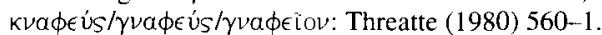

14 Even so MacDowell (1971) 102 and 278 prints $\gamma \nu^{-}$.

15 Cf. Cratinus fr. 303; Allen (1987) 106-11, referring to Schade (1908). In Aristophanes there is no conclusive evidence: Holzinger (1940) 43.

16 Compare Eccl. 415 where of precedes kvaфñs. The only other relevant word in Aristophanes is Ar. fr.

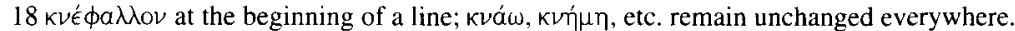

17 Holzinger (1940) 43 reads $\kappa \nu$ - and inserts kaí before $\kappa \nu \alpha \phi \in u ́ \in \mathrm{L}$, but this spoils the parallelism of the linebeginnings in Plut. 164-8 (all starting with simple ó $\delta \dot{\epsilon}$ ).

18 Even if the orthography conceals no more than a change from a fortis stop to a lenis stop (Threatte (1980) 560 ), some kind of change has obviously taken place.

19 Cf. Chantraine (1968-80) 547, s.v. kváTTw. 
role, ${ }^{20}$ all the more since we will come across such influence elsewhere, for instance as we turn to word formation $(\S 2.2)$.

\subsection{Word formation}

In the area of word formation, there are no sudden changes either. As time passes, some formational patterns gain in prominence and others lose their productivity. Sometimes such a move does not affect the language as a whole, but only certain sociolects. The most famous Aristophanic example is the liking for the suffix - $\leftarrow$ Kós among the dandies ridiculed in Knights (Eq. 1378-81). The point there is not so much the spread of -ıкós

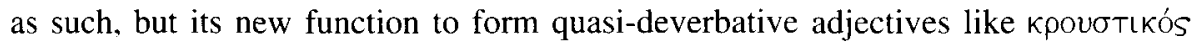
'incisive'.21 This functional extension facilitated the rocket-like spread of -lkós in fourth-century Greek. However, Plutus does not contain any prominent -LKós adjectives, perhaps because most of the new -ıkós words, unlike the average language of Plutus (as will be argued throughout this paper), still belonged to a cultivated register.

The case of colloquial formations in -kpos or $-\chi \rho^{\prime} \rho^{22}$ is hardly more promising. Plutus has the only Aristophanic occurrence of $\pi \epsilon \mathcal{V} \chi \chi \rho \rho^{\prime} S$ (instead of $\left.\pi \epsilon ́ v S^{2}\right)^{23}$ and the

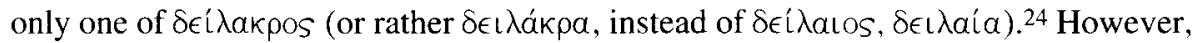
both times the speaker is the old hag who wants to get her lover back (Plut. 973, 976). At best, we might therefore think of an individualizing feature. Note that the only other example of $\delta \epsilon i \lambda \alpha \kappa \rho o s / \delta \epsilon L \lambda \alpha$ k $\rho \alpha$ in Greek literature occurs in a frivolous woman's lovesong (Carm. Pop. 27 Bergk = 853 Campbell).

If we exclude such material, we are left with one observation that does exemplify a development in word formation. Aristophanes uses very few adjectives in - $\omega \delta \eta \bar{s}: 14$ lexemes totalling 16 attestations. Five of these 16 occur in lyric contexts and are purely

20 This is implied by Schwyzer (1939) 414 who, because of Alcaeus fr. 338.8 V. $\gamma v$ ó $\phi a \lambda \lambda o v$, regards $\gamma \nu$ as the Proto-Greek anlaut (assimilated from $* k n-b h$-); only in Attic $\gamma \nu-\phi$ - would have been assimilated once again to $\kappa \nu-\phi$-, and the later adoption of $\gamma \nu-\phi$ - would be a 'return' to the panhellenic variant.

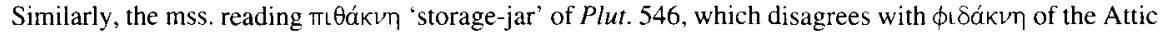
inscriptions (Threatte (1980) 468), may represent a return to the original version preserved in other dialects (cf. in Middle Comedy Eubulus fr. $130 \pi\llcorner\theta a ́ k \nu a)$ ).

21 Cf. Willi (2003) 139-45, elaborating on Peppler (1910), Dover (1970) 13 and (1997) 118-19, and others.

22 On the colloquial character of these suffixes see Chantraine (1933) 225 with $\mathrm{n}$. 1. A further rare formation

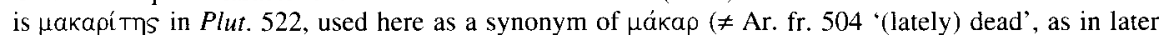
Greek: e.g. Men. fr. 554, Plut. Mor. 120c, Luc. D. Meretr. 6.1).

23 The occurrences of $\pi \epsilon v$ X $\chi$ ós in 'high' literature (e.g. Alc. fr. 360 V., Thgn. 165, 181, Pind. Nem. 7.19)

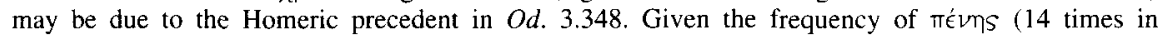
Aristophanes, 5 in Plutus), the rarity of mєVlXpós in Aristophanes is remarkable.

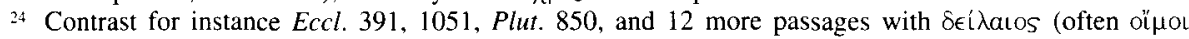

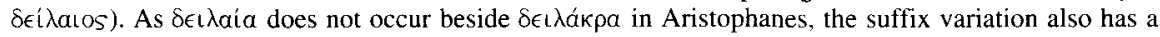
gender-linguistic dimension and can be compared with other features where women are made to prefer more colloquial forms (Willi (2003) 193-4). In colloquial speech the derivative $\delta \epsilon \iota \kappa \lambda \alpha \kappa p i \omega v$ is also applied to men: Pax 193 (Hermes to Trygaeus, who responds with $\gamma \lambda i$ í $\chi \rho \omega \nu$ based on $\gamma \lambda i$ í $\chi \rho \circ$ ), $A v$. 143 (the Hoopoe). 
poetic; they do not reveal anything about spoken Attic (Av. $1067 \epsilon \dot{v} \omega \delta \eta \bar{s}, A v .1746$

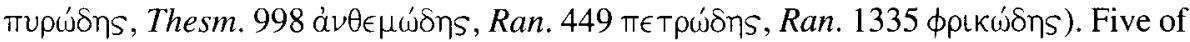
the remaining 11 attestations occur in Plutus. Here, too, are the only lexemes that are repeated: $\sigma \phi \eta \kappa \omega ́ \delta \eta S$ 'waspish' (Plut. 561, 562) and $\pi \rho \in \pi \omega \dot{\delta} \eta S$ 'fitting' (Plut. 793, 797). The latter, $\pi \rho \in \pi \omega \dot{\delta} \eta s$, is one out of two that occur in a trimeter, where linguistic realism is strongest. ${ }^{25}$ All the rest are used in anapaests, including $\sigma \phi \eta \kappa \omega \dot{\delta} \eta \bar{s}$ and $\gamma a \sigma T p \omega \dot{\delta} \eta \bar{s}$ 'pot-bellied': Penia is comparing rich and fat to poor and lean people (Plut. 560-1).26 The meaning 'pot-bellied' nicely illustrates the change of tone from high-flown words like $\alpha \nu \theta \in \mu \omega \dot{\delta} \eta s$. As for $\pi \rho \in \pi \omega \delta \eta \eta$, the word occurs both times in the phrase $\pi \rho \in \pi \omega \delta \epsilon \in s$ $\dot{\epsilon} \sigma \tau \iota \nu$, which stands for $\pi \rho \epsilon \epsilon \epsilon l:$ a full verb is replaced by an adjective with auxiliary. This and similar syntactic phenomena will be discussed below ( $\$ 2.3$ ). For now it is sufficient to retain that Plutus is Aristophanes' only play in which -wons adjectives seem to be a living formational type also outside poetic registers.

This agrees with what is known about their history. It was long believed that $-\omega \delta \eta \bar{S}$

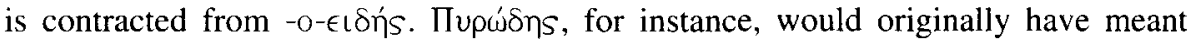
'looking like fire', hence 'fire-like, fiery'. However, historical phonology strongly speaks against this and Jacob Wackernagel suggested a more convincing derivation: $-\omega \delta \eta \bar{s}$ belongs to ő $\zeta \omega$ 'to smell of something'. As the verb ö $\zeta \omega$ can be used like English

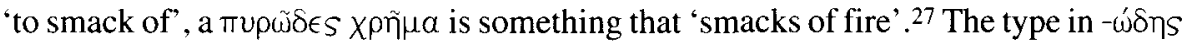
is reasonably well-attested only from the second half of the fifth century onward - first with Sophocles and Herodotus -, and one has to wait for post-classical authors such as Polybius to witness its sudden success. The spread is mainly due to the innovation of building deverbative adjectives in $-\omega \delta \eta \bar{s}$, which closely resemble participles or quasideverbative adjectives in -TLKós. The first example of this new type in - $\omega \delta \eta \bar{s}$ is precisely $\pi \rho \epsilon \pi \omega ́ \delta \eta s$, twice attested in Plutus. ${ }^{28}$ Since the adjectives in - $\omega \dot{\delta} \eta \mathbf{s}$ are extremely frequent in the Ionic dialect of the Hippocratic treatises, a foreign origin for the vogue is most likely.

So far, then, our observations on the linguistic character of Plutus already alert us to watch out for (1) further foreign intrusions into Aristophanes' Attic, and (2) additional evidence for a shift towards a lower, more colloquial, level of language.

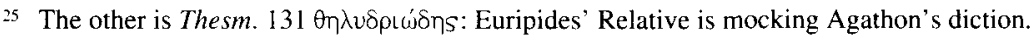

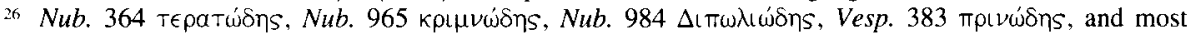

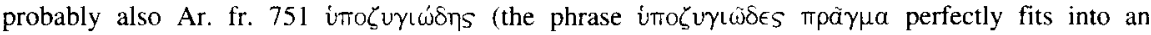
anapaest).

27 Wackernagel (1889) 44-7, referring to passages like Ar. Nub. 49-52, 398, 1007, Lys. 616-17, 665/6, 689/90. According to Wackernagel the 'suffix' originated in adjectives like $\theta v \omega \dot{\delta} \eta \mathrm{S}$ 'smelling of incense',

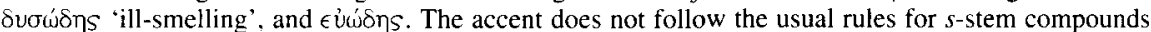

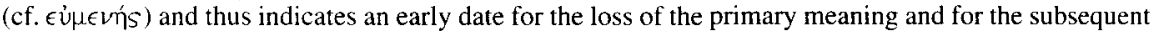
transformation of - $\omega \delta \bar{\eta}$ s into a suffix; this then took on some of the functions of the (hypothetical)

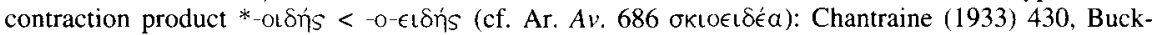
Petersen (1944) 698.

28 Cf. Wackernagel (1889) 47, who cites Xenophon, Plato, and Isocrates as the first authors to use $\pi \rho \epsilon \pi \omega ́ \delta \eta$ s. The application of $-\omega \delta \eta S)$ is semantically similar to 'fitting for $x$ ' $(=\pi \rho \in \pi-)$. 
However, it is not until we turn to syntax $(\S 2.3)$ and pragmatics $(\S 2.4)$ that we start to have more plentiful evidence for innovative use of language in Plutus.

\subsection{Syntax}

The first syntactic point links up with the issue just raised with regard to $\pi \rho \epsilon \pi \tilde{\omega} \delta e^{\prime} S$ $\dot{\epsilon} \sigma T \iota$ for $\pi \rho \epsilon \in \pi \epsilon \iota$ ( $\$ 2.2$ ). The replacement of a full verb by an adjective with auxiliary is paralleled by periphrastic expressions with participle + full verb. In the verbal paradigm of classical Greek such periphrasis is sometimes mandatory (cf. e.g. the 3rd

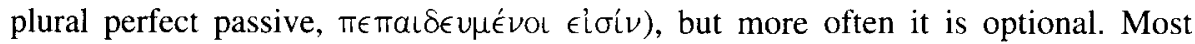
commonly it occurs in the perfect or pluperfect, especially with neuter subjects. Consider, for instance, the sentence at Plut. 160-1:

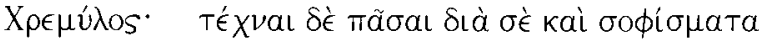

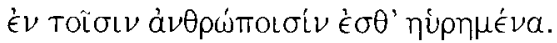

Chremylus: And all crafts and skills that exist among mankind have been invented because of you.

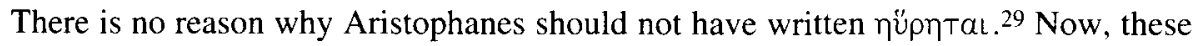
'irregularities' are found from Acharnians onward, but they are common only in Aristophanes' fourth-century plays. Nearly half of some 22 or $23^{30}$ examples occur in Ecclesiazusae and Plutus. ${ }^{31}$ Moreover, Plutus shows an exceptional freedom with this

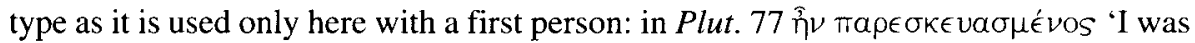

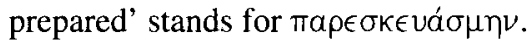

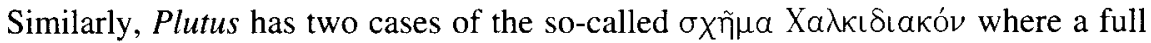
verb is replaced by present and perfect active participles, ${ }^{32}$ as in Plut. 49 É $\sigma \tau i ~ \sigma v \mu \phi \epsilon ́ p o v$

29 The $\sigma \times \tilde{\eta} \mu \alpha$ 'ATrLKóv (ntr. pl. subject with 3rd sg. verb) is firmly observed in Aristophanic comedy: cf. Wackernagel (1926) 101-3, Poultney (1963) 362-3, and Willi (2003) 254.

${ }_{30}$ Not all cases are easily classifiable: I exclude possessive constructions with the copula (e.g. Ach. 512

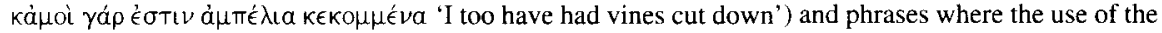

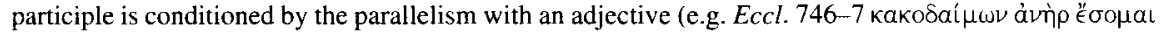

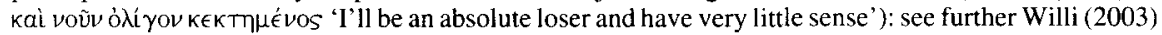
152-3, also on similar cases with the present participle not counted below (e.g. Plut. 371).

31 Eccl. 61, 139, 458, 970, 1139, 1147, Plut. 77, 161, 626, 1192; cf. Ach. 1089, Eq. 230, 844, Vesp. 127, Pax 566, Av. 1291, 1301, Lys. 26-7, 175, 1038, Thesm. 75 (cf. 1119), Ran. 761 (cf. 721), and also with a future perfect $A v .655 \ddot{\epsilon} \sigma \epsilon \sigma \theta 0 \nu \dot{\epsilon} \pi T \epsilon \rho \omega \mu \epsilon \in \omega \omega$.

32 Cf. Lesbonax Gramm. fr. 5 Blank (Sammlung griechischer und lateinischer Grammatiker 7), who only refers to the present participle although the usage with the perfect active participle (here marked with *) is identical: Eq. 468, 854*, Pax 334, Av. 652, 1473*, Thesm. 77, Plut. 49, 867*. In Lys. 101 and 729-30

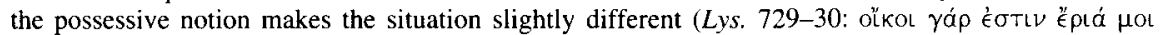

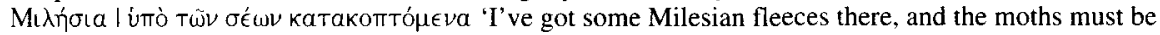

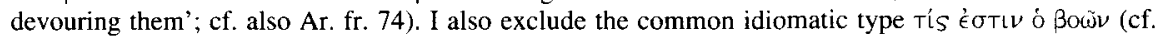
Björck (1940) 89-92) as well as passages where the participle stands for a relative clause (e.g. Eccl. 1086, 1094: cf. Björck (1940) 15, 102-3). 


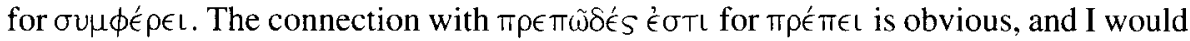

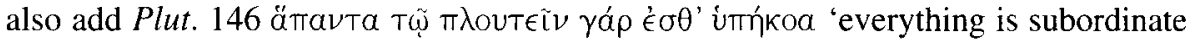
to being wealthy'. Instead of iTakovi $\in \mathrm{L},{ }^{33}$ Aristophanes preferred the quasi-participial imíkoos, an adjective he uses only here. In all these cases we see a 'shift of focus from the action onto the property', as Björck puts it, ${ }^{34}$ and a tendency towards a type of verbal periphrasis which is well known from fourth-century literature. ${ }^{35}$ Holzinger acutely observes: 'Im IV. Jahrh. ... muss dieser Sprachgebrauch schon recht weit gereicht

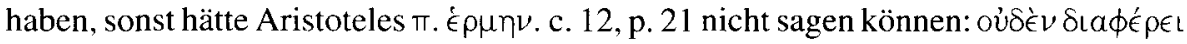

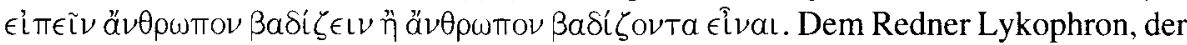
$\beta a \delta i \zeta \omega \nu$ '́oTív gegenüber $\beta a \delta i \zeta \epsilon L$, wenn auch nicht aus sprachlichen Gründen, verwirft, tritt er $\Phi v \sigma$. ák $\rho$. A p. 185 b 30 entgegen. ${ }^{36}$ How to account for the usage is more difficult to say. Since other writers are just as fond of the new constructions as the comedians, one must not invoke too quickly some kind of 'koineisation' process, even though this too may have contributed to the spread of the structure and Thumb diagnosed a 'Vorliebe des griechisch schreibenden Römers für die Conjugatio periphrastica' in later times. ${ }^{37}$

A second major ${ }^{38}$ syntactic point concerns the loss of Attic peculiarities. In Attic, final clauses are traditionally introduced by the conjunction $0 \ddot{\pi} \omega s$ with or without $\ddot{a} v$, but in Plutus there is only a single example left (Plut. 225); four years earlier, Ecclesiazusae had a total of seven. ${ }^{39}$ In fifth-century texts, "iva is common in Herodotus, but Thucydides and the Attic inscriptions clearly prefer ö $\pi \omega s .{ }^{40}$ Thus, the success of ¿va in Attic Greek from about 400 BC onward is likely to be related to the 'birth-pangs' of Koine Greek, an increasing de-Atticisation or Ionicisation of Attic. ${ }^{41}$

The same conclusion is valid for the dual, which is lost at an early date in Ionic, but long retained in Attic. The dual is much weaker in Plutus than elsewhere in Aristophanes. As with the preceding point, the break cannot be attributed exclusively

33 Uтакоúw 'to obey' is used in Ecclesiazusae (Eccl. 515; elsewhere in Aristophanes 'to listen, give heed to').

34 Björck (1940) 28 ('Verlagerung des Schwergewichts von der Handlung auf das Eigenschaftliche'); cf. also Coseriu (1975) 16-18 ('partialisierende Schau'), Rutherford (1903) 249, and Willi (2003) 153.

35 Cf. Björck (1940) 36. Aerts (1965) 25-6, and Dietrich (1973) 201-9; in Middle Comedy note e.g. Antiphanes fr. 4, 54.3, 122.11, Anaxandrides fr. 57.4.

36 Holzinger (1940) 14

37 Thumb (1901) 152.

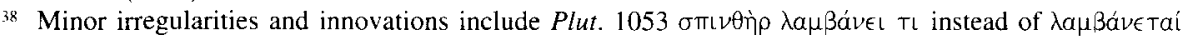

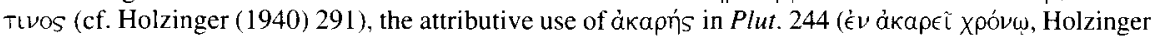

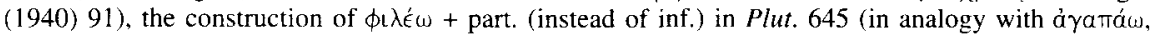

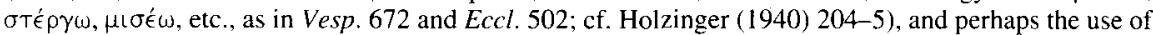
$\hat{\omega}$ Tô in addressing two people in Plut. 66 (van Leeuwen (1904) xix).

39 According to Todd (1932) the figures are: Ach. 3, Eq. 0 (!), Nub. 5, Vesp. 4, Pax 3, Av. 2, Lys. 14, Thesm. 2, Ran. 5, Eccl. 7, Plut. 1. The absence of ötwS (äv) in Knights may be related to the predominance of lowly speakers in that play (slaves and the sausage-seller).

40 For statistics see Willi (2003) 264-5, mainly based on Weber (1884) and (1885); cf. Amiguès (1977) 99.

+1 On this see for instance Thumb (1901) 202-53 and more recently López Eire (1991), (1993), and (1996). 
to the late date of the play since it is too abrupt to reflect a natural development; more plausibly, it bears witness to a conscious change in tone on the part of the author - a point which will be discussed below $(\$ 3)$. The modifications concerning the dual do not so much lie in the use of nominal and verbal forms, ${ }^{42}$ but in the increase of incongruent agreement of duals and plurals ${ }^{43}$ and in the replacement of dual pronouns by plural pronouns. Most notably, a plural is used in 50 to 60 per cent of the pronominal slots where we should expect a dual. ${ }^{44}$ In Ecclesiazusae there is not much comparative evidence, ${ }^{45}$ but in the play before, Frogs, the corresponding number is just 11 per cent. ${ }^{46}$

Of course not all syntactic changes can be explained likewise, by reference to interdialectal developments and the transformation of Attic into Koine Greek. Leaving aside erratic changes without an immediately discernible motivation (such as the increased use of articular infinitives) ${ }^{47}$ as well as changes without further impact, ${ }^{48}$ a third group of innovations consists of intradialectal 'bottom-up changes': tendencies which originate in lower-class Attic and gradually conquer further territory. Here, too, Aristophanes seems to have become more 'open-minded' in the later stages of his career. ${ }^{49}$ For instance, the co-ordinating particle pairs $T \epsilon-T \epsilon$ and $T \epsilon-\kappa \alpha i$ are virtually

42 Cf. especially Cuny (1906) 183, but also Cuny (1906) 235-42 for the use of a plural instead of an expected dual noun. There are 9 exceptions in Plut.: contrast Ach. (with the exception of the dialect parts), Pax, and Ran. with 4 each, Nub., Av., and Eccl. with 3 each, Eq., Vesp., Lys., and Thesm. with 1 each.

43 See Plut. 73, 429-30, 471, 482, 484, 509, 532, 608-9, 733-4, 735-6; cf. also Poultney (1963) 363-7. According to Cuny (1906) 508, Plutus also has fewer duals than the preceding plays.

t Contrast (depending on the interpretation of particular passages) 14 to 17 examples with the plural for the dual (Plut. 74, 200, 226, 418, 428, 457, 462, 470, 471, 487, 532, 593, 604, 608, 619, 870, 928) against 11 with the expected dual (Plut. 54, 218, 401, 433, 437, 467, 482, 484, 509, 563, 958).

+5 Cuny (1906) 170 cites 2 examples of dual observation but none of replaced dual pronouns.

46 This is very low but cf. Eq. $16 \%$, Vesp. $8 \%, A v .26 \%$. Pax with $43 \%$ and Thesm. with $67 \%$ are difficult to compare because the overall number is low in these plays (Pax 7, Thesm. 3; cf. Eq. 12, Vesp. 12, Av. 35, Plut. 28). These figures are based on Cuny (1906) 168-79, who does not cite any cases of replacement in the remaining plays and who excludes ambiguous cases (Eq. 53, Vesp. 67, Av. 271, Ran. 756, Plut. 945).

47 Especially with prepositions and in the genitive and dative; in the nominative and accusative the use of articular infinitives is traditional (cf. in general Birklein (1888); for Aristophanes, Willi (2003) 149-52, where the phenomenon is placed in a wider context). Birklein (1888) 38 gives the following statistics for Aristophanes: $A c h .0$ nom.-acc. ( 0 with prep.) : 0 gen.-dat. ( 0 with prep.) $=0$ total; Eq. $1(0): 2(1)=3$; Nub. $9(2): 1(1)=10 ;$ Vesp. $4(1): 5(4)=9 ;$ Pax $1(0): 0(0)=1 ; A$ v. $3(0): 1(0)=4 ;$ Lys. $2(0): 0(0)$ $=2 ;$ Thesm. $0(0): 2(0)=2 ;$ Ran. $11(1): 2(2)=13 ;$ Eccl. $2(0): 2(2)=4:$ Plut. $11(1): 6(2)=17$.

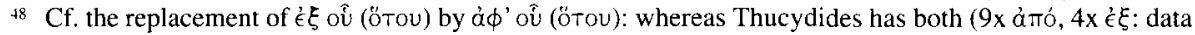
according to an online $T L G$ search on <www.tlg.uci.edu>), Herodotus exclusively uses $\dot{\epsilon} \xi(6 \mathrm{x})$. In comedy, à $\phi$ ' ơ first occurs in Ar. fr. 31 (of $414 \mathrm{BC}$ ), but apart from that only in Plutus (3x: Plut. 968, 1113,1173 ) as well as Middle and New Comedy (Alexis fr. 200, Men. fr. 352); $\dot{\epsilon} \xi$ of (*ötov), on the other hand, is typical of the Aristophanic plays before Plutus (also Plut. $85^{*}$ ) as well as other authors of Old Comedy (Ach. 17*, 596*, 597*, Eq. 4, 644, Nub. 528*, 1351*, Vesp. 887, Av. 322*, 694, 1515, Lys. $108,759,866$, Crates fr. $39^{*}$, Eupolis fr. $274^{*}$, Hermippus fr. 63.2, Pherecrates fr. 75.6).

49 Sometimes it is difficult to decide whether one is dealing with an occasional colloquial licence or a real change. Thus, 2 out of 6 possible examples of a potential optative without äv occur in Plutus (Vesp. 472, Av. 180, Lys. 839, Thesm. 872, Plut. 374, 438). Although most of them are usually emended, it is wiser to state that the phenomenon is 'excluded only from the most rigid and fastidious sorts of writing' (Bers (1984) 135; cf. Hale (1893) 180-3 and 202, Slotty (1915) 139-42, Wackernagel (1926) 236-7, MacDowell (1971) 197, Willi (2003) 259). 
given up in favour of the less literary kai-kai. ${ }^{50}$ Conversely, the preposition ws 'to, towards (someone)' is increasingly common in the fourth-century plays: 18 examples in Ecclesiazusae and Plutus contrast with just 26 in the remaining nine plays.51 If Wackernagel's etymological suggestion is correct and prepositional is is a fossilised directional accusative of the root noun preserved in Latin os 'face' (compare English in front of $), 52$ the preposition must be very old, even though it becomes established in literature only at a relatively late point. ${ }^{53}$ Popular language had retained an archaic usage ${ }^{54}$ and eventually succeeded in introducing it into higher registers. Incidentally, frequency changes

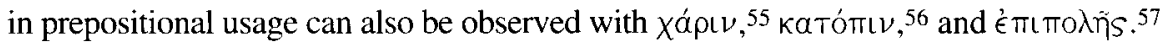

However, the most important 'bottom-up' change in the syntax of Plutus is a distinct trend towards redundancy. There are many features exemplifying this, but the following two are the most noticeable. ${ }^{58}$ The first one is the use of prepositional phrases with verbs that do not normally, or traditionally, require such a phrase. The standard

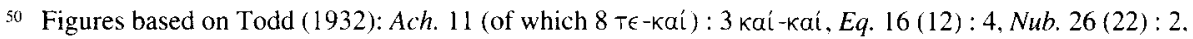
Vesp. 8 (5): 4, Pax 14 (10):2, Av. $16(6): 3$, Lys. 17 (11):6, Thesm. 14 (11): 2, Ran. 21 (17):3, Eccl.

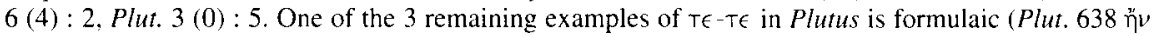

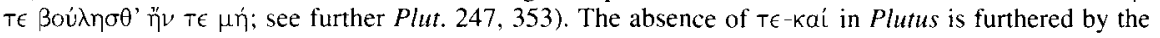
predominance of trimeters in the play (cf. Holzinger (1940) 303 on the avoidance of $\tau \epsilon$-Kaí in trimeters) but since $\tau \epsilon-k a i$ does occur in fourth-century oratory (cf. Denniston (1954) 511-13), it must have existed in spoken Attic too.

51 Figures based on Todd (1932): Ach. 4 (1 in 308 lines), Eq. 2 (1/704), Nub. 2 (1/756), Vesp. 2 (1/769), Pax 2 (1/683), Av. 4 (1/441), Lvs. 2 (1/661), Thesm. 6(1/205), Ran. 2 (1/767), Eccl. 8(1/148), Plut. 10(1/121). Because of the parallelism with Plut. 242 is, most editors replace mss. Els by is in Plut. 237, pace Holzinger (1940) 85-90.

52 Wackernagel (1893) 16-18 n. 2; the etymology neatly accounts for the fact that is, unlike mpós, is used exclusively with persons.

5.3 is occurs once in Homer and once in Herodotus, but otherwise only in Attic: rarely in tragedy, more frequently in fourth-century prose (cf. Schwyzer-Debrunner (1950) 533-4). For the equivalence of is and $\pi \rho$ ós contrast e.g. Plut. 32 ws (most mss., not to be corrected with Coulon (1908) 153) with Plut.

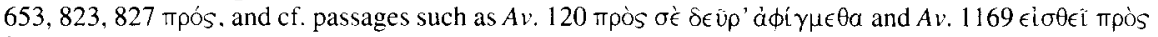

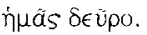

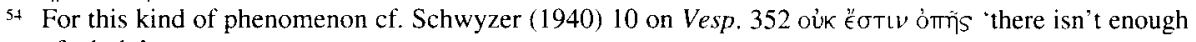
of a hole'.

$55 \quad \chi \alpha$ á $\nu$ with the 'prospective' meaning 'for the purpose of occurs 4 times in Plut. (53, 154, 260, 1009), 3 times in the earlier plays (Thesm. $586, E c c l .140$, both spoken by women; Ran. 1418); the 'retrospective' meaning 'because of, in return for' is common from Acharnians onward (Ach. 892, 915, 1051, 1232, Eq. 268, Vesp. 62. Thesm. 127) and the synonym ÉvєKa shows no remarkable distribution (6 times in Plut., 53 times elsewhere).

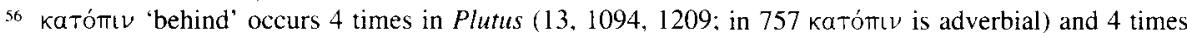

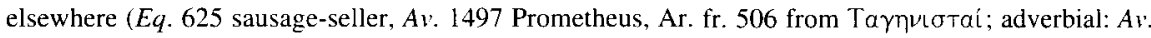
1150).

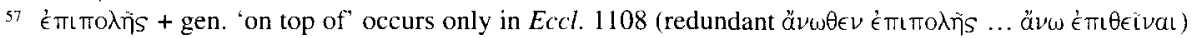

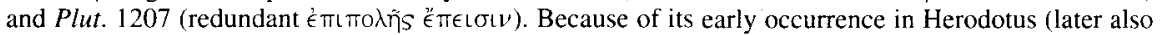
in Plato and Xenophon), it might be an Ionism (cf. below $\$ 2.6$ on other lexical Ionisms).

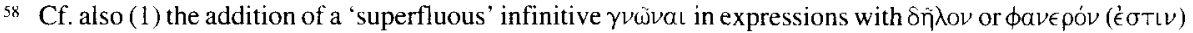
ÖTŁ ('it is clear to recognise that' instead of simple 'it is clear that'), both Aristophanic examples of which occur in Plutus (48-9, 489; on Plut. 48-9 cf. van Leeuwen (1904) xix, 'aut solum adiectivum aut $\rho a ́ \delta ı s$

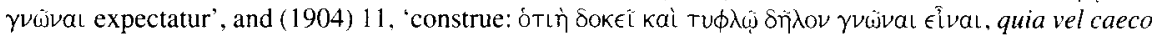

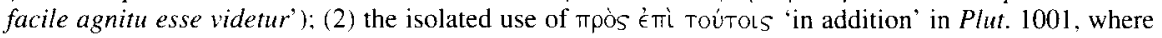
either (adverbial) $\pi \rho o ́ s$ or mpòs Toútols (cf. e.g. $N u b .720$ ) would be expected; (3) the use of $\dot{\epsilon} v \theta \dot{\alpha} \delta \epsilon$ 
construction of $\sigma u ́ v \in(\mu \mathrm{t}$ 'to be together with' is a simple dative, as in Plut. 774-5 where Plutus, after his healing, exclaims:

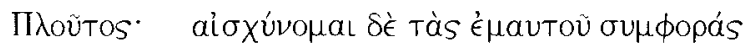

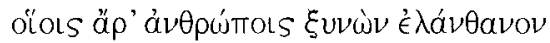

Plutus: I am ashamed of my past circumstances - the kinds of men with whom I now perceive I consorted unawares!

This regular construction is found 19 times in Aristophanes, ${ }^{59}$ but in Plutus an alternative

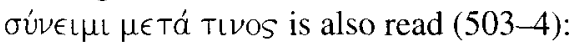

\section{Хрє

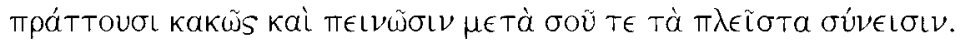

Chremylus: And many who are very virtuous are in a bad way, and starve, and live most of their lives in your company.

One would hardly notice this if the situation with émouaı 'to follow' were not exactly the same: four times "̈tropal is used with the dative, as we expect for classical Attic,

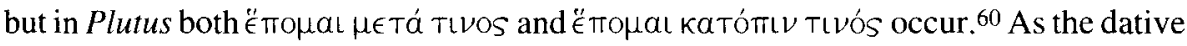
case will disappear in (much) later Greek, one wonders whether these are the first

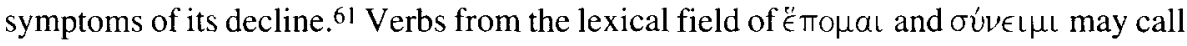
for such semantic support more than other verbs, for Plutus also displays the

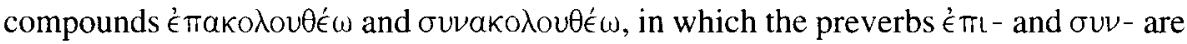
redundant; 62 these, however, belong to a whole series of verbs with redundant preverbs which will be discussed later $(\$ 2.6)$.

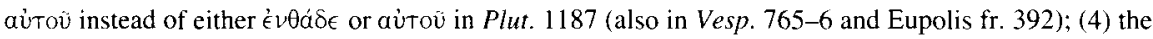
addition of tois tpótrovs to the comparative $\beta \in \lambda T i \omega \nu$ which in itself expresses the notion of character quality (only in Eccl. 214 and Plut. 105; cf. van Leeuwen (1904) xix and contrast e.g. Thesm. 810); (5) the parallel use of $\hat{\eta} \mu \eta^{\prime} v$ and $\tilde{E}^{\top} \mathrm{t}$ in threats where either one or the other would be sufficient (only in Eccl. 1034, Plut. 608: cf. van Leeuwen (1904) xix).

5. Including 6 times in Plutus and Ecclesiazusae: Eq. 1287, Nub. 1404, Vesp. 475, 1222, 1256, 1273, 1460 , Av. 418, 650, 704, 1487, Ran. 959, Eccl. 38, 340, 619, 898, Plut. 321, 775.

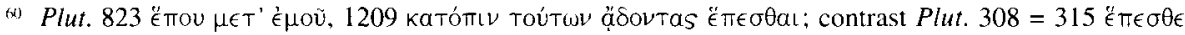
$\mu \eta T p i$ (according to the scholia not Aristophanes' wording but a proverbial expression), Vesp. 1278, Pax

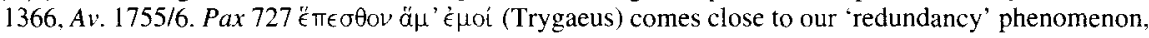
but äนa need not have given up all of its adverbial meaning 'together, at once'; it reinforces, rather than replaces, the dative construction.

6. Cf. Thumb (1901) 125 on тro $\epsilon \mu \tilde{\omega} \mu \epsilon \tau a ́$ etc. in Egyptian papyri; on the later loss of the dative see Humbert (1930).

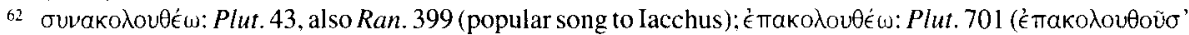
$a ̈ \mu a$ plausibly conjectured by Reisig; for the following ä $\mu \alpha$ cf. Theopompus Com. fr. 61 ), Eccl. 479, Vesp.

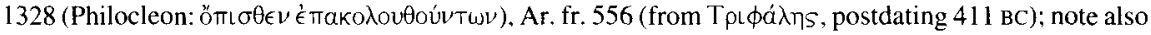

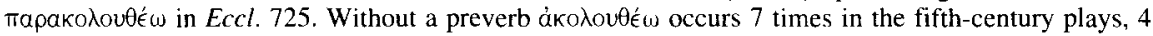
times in Ecclesiazusae, and 5 times in Plutus, but as usual the innovative variants tell us more about language history than the traditional ones. 
The second 'redundancy' phenomenon to be considered here is the use of the numeral $\epsilon i s$ together with the particle $\gamma \epsilon$ and the indefinite pronoun $T L S$, in the function of $T L S$ alone $\left(\epsilon \hat{I} S \gamma^{\prime}\right.$ TIS $\left.=T L S\right)$. In this collocation, the force of the numeral is about as weak as in English impersonal 'one' or in colloquial German einer for (irgend)jemand (da ist einer $(\approx \epsilon \hat{L} S)$ gekommen $=d a$ ist wer $(\approx T L S)$ gekommen $=d a$ ist jemand gekommen $;{ }^{63}$ in later Greek $\epsilon$ is even takes on the functions of an indefinite article. ${ }^{64}$ Although this usage comes into being long after the time of Plutus, the use of $\epsilon \hat{\epsilon} \bar{S} \gamma \dot{\epsilon}$ $T I S$ for 'someone' is a first step in the same direction. Aristophanes has it once in Thesmophoriazusae, twice in undated, presumably late, fragments, and twice in our play. ${ }^{65}$ Considering the semantic weakening of the numeral $\epsilon \hat{i}$ s one might speak of a first step towards its grammaticalisation, for 'the most important functional grammaticalization process is called desemanticization' and 'this is the process by which lexical meanings shift to the meanings of grammatical items.' 66 What unites the present phenomenon and the one mentioned before is the loss of 'semantic force': $\sigma u ́ v \epsilon \iota \mu$ begins to require a preposition to express 'with', and Tis begins to require the addition of $\epsilon i s$ in order to express what it used to express on its own.

\subsection{Pragmatics}

Once we have acknowledged this trend towards semantic weakening $(\$ 2.3)$, we easily understand what happens in the field of linguistic pragmatics. Here the most characteristic feature is the speakers' constant wish to emphasise their statements. Again a brief summary will be sufficient to elucidate what is an omnipresent phenomenon in Plutus. Let us take a simple word like oúseis 'no one' and look at the complaints of the priest of Zeus Soter (Plut. 1182-3):

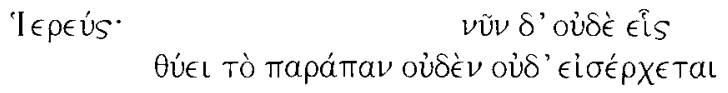

Priest: But now, no one sacrifices anything at all; they don't even come into the sanctuary

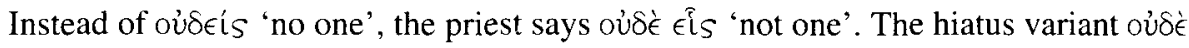
$\epsilon i s$, which historically speaking reintroduces the original form, has an emphasising

63. Note that $\epsilon$ is TIS retains more of the original force of $\epsilon$ is than $\epsilon$ is $\gamma \dot{\gamma}$ TIS: $\in$ is TIS means 'a single someone $=$ an unnamed individual', not just 'someone'.

tot Cf. Kuhlmann (1997/8).

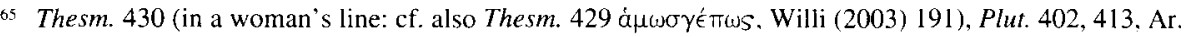

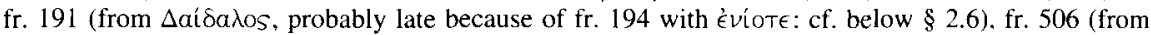

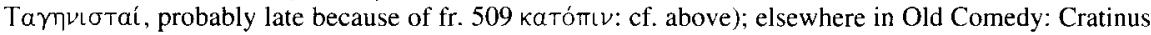
fr. 270 , Pherecrates fr. 82.

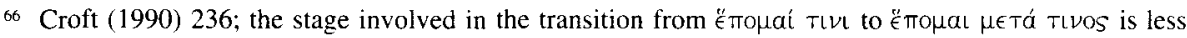
advanced, but it too is a case of functional loss and reinforcement like the one seen in French ne $\rightarrow$ nepas (on which see Croft (1990) 238). 
effect similar to the one that was reached much earlier when oü TIS was replaced by the stronger oujetis. The reintroduction of the hiatus, and with it the aspiration of $\epsilon \hat{i} S$, will later lead to the Hellenistic form with $-\theta-$, ov $\theta \in i^{\prime} S .{ }^{67}$ With Plutus, we are still one

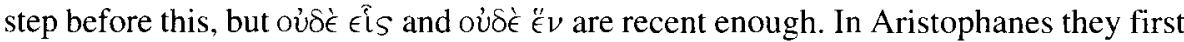
occur in Lysistrata and Frogs, once in each play, and then four times in Plutus, 68 Menander will have them more than 30 times. Thus, Plutus (but not Ecclesiazusae,

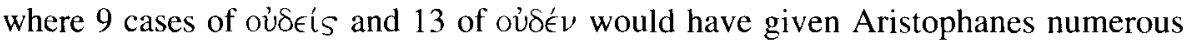
opportunities to employ the younger variants) adopts a fourth-century fashion which,

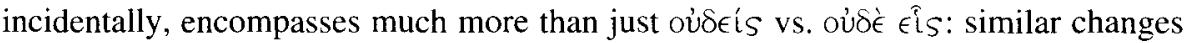

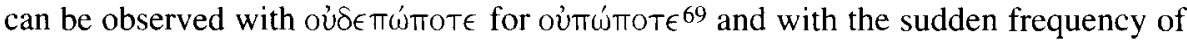

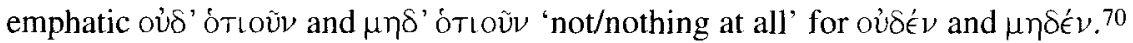

Turning to positive statements, an increase of emphasis is again easily detected in Plutus. Not only do its characters speak more often of 'all x' than those in the earlier plays, ${ }^{71}$ they also seem to feel that it is no longer sufficient to say 'all $x$ ', and they say 'all $x$ together' instead: about 50 per cent of the Aristophanic examples of ámaรátavTes occur in the two fourth-century plays. Moreover, the relation between the personality of a speaker and the use of such a form is lost, whereas earlier on slaves or simple farmers like Trygaeus had them more often than other characters. ${ }^{72}$ In Plutus, on the other hand, to say $\alpha \pi a \xi \alpha$ a $\pi \alpha \nu \tau \epsilon S$ is not the prerogative of Carion, the slave most often seen and heard on Aristophanes' stage. For Carion even áma $\xi \dot{a} \pi \alpha v \tau a$ is too weak on one occasion: he prefers $\sigma v \lambda \lambda \hat{\beta} \beta \delta \eta \nu$ äravтa 'all things taken together' ${ }^{73}$

67 Cf. in general Wackernagel (1928) 114 and 268-70 and Moorhouse (1962) 245-6, also on non-Attic examples (e.g. Epich. fr. 213, Hipponax fr. spurium 64 W.).

6* Lys. 1045 (chorus), Ran. 927 (Euripides), Plut. 37, 138, 1115, 1182. In Old Comedy cf. Crates fr. 16.1, Cratinus fr. 335, Eupolis fr. 392.4. The separated type ou $\delta$ à $v$ is (Eq. 573, Vesp. 72, Plut. 137) is a retained archaism (Wackernagel (1928) 269).

69 оüтஸ́тоте occurs 7 times in Aristophanes but never in Plutus (or Ecclesiazusae), whereas 3 out of 10

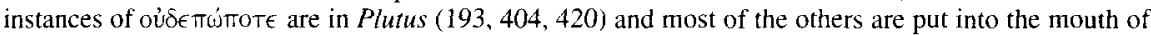
informal speakers (Ach. 17, 34: Dicaeopolis, Vesp. 14: a slave, Thesm. 490: a fake woman; once in Eccl: 384). Cf. further Wackernagel (1928) 269: ' $\pi 0 T \epsilon$ und $\pi \omega$ haben sich neben der Negation auch im Attischen gehalten, nur dass sich davor nach dem Muster der oủófis-Gruppe das steigernde oủót einstellte, das eigentlich zu einem Indefinitum nicht passt'.

70 Plut. 385, 457, 599, 1030; earlier: Lys. 776 (oracular, cf. in dactylic poetry Thgn. 64), Nub. 344 (Strepsiades). Vesp. 598 (Philocleon); cf. Wackernagel (1928) 270.

7 Cf. the increasing use of ätas: in Plutus there are 23 cases, i.e. one every 53 lines and twice as many as in the average fifth-century play (Ach. $13=1 / 95, E q .23=1 / 61, N u b .15=1 / 101$, Vesp. $20=1 / 77$, Pax $9=1 / 152$, Av. $16=1 / 110$, Lvs. $11=1 / 120$, Thesm. $13=1 / 95$, Ran. $7=1 / 219$, Eccl $.18=1 / 66)$. Similarly, simple $\pi \dot{\alpha}$ s becomes more frequent $($ Ach. $23=1 / 54, E q .21=1 / 67$, Nub. $20=1 / 76$, Vesp. $19=1 / 81$, Pax $34=1 / 40$, Av. $74=1 / 24$, Lys. $31=1 / 43$, Thesm. $31=1 / 40$, Ran. $14=1 / 110$. Eccl. $37=1 / 32$, Plut $.41=$ 1/29).

72 Plut. 111, 206, 760, 1109, Eccl. 217, 719, 766, 1148, Ar. fr. 2 (from Aiołơíkwv, Aristophanes' last comedy); earlier: Eq. 845 (Paphlagon), Pax 106, 247, 542, 655. 870 (3 times used by the simple farmer Trygaeus, once by a slave), Av. 1539 (Prometheus), Thesm. 515, 550 (both in a woman's or pseudowoman's line).

7. Plut. 646: the adverb $\sigma u \lambda \lambda \hat{\beta \delta} \eta \nu$ occurs once again in Aristophanes (Vesp. 657: Bdelycleon), instead of ämas. 
The same tendency appears when we consider intensifying adverbs like mávv. The people of Plutus use máv $v$ nearly twice as often as the people of Frogs, the play ranking next to it. ${ }^{74}$ They also have two thirds of all the Aristophanic occurrences of adverbial Tò mapátav (one of which is quoted above in the line of the priest of Zeus). ${ }^{75}$ Just as $(\ddot{\alpha}) \pi a v$ is here strengthened through the addition of $\pi a \rho-$, the text of Plutus also reads

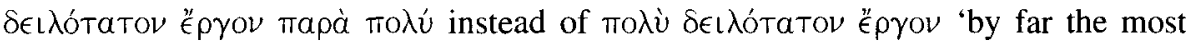

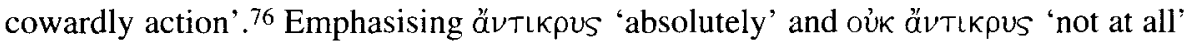

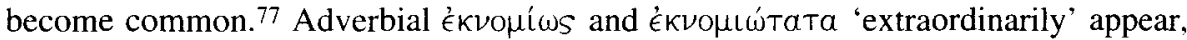
for the first and last time in all of Greek literature. ${ }^{78}$ With $a \sigma \sigma \lambda \gamma \gamma \tilde{\omega} s$ 'outrageously', too, Plutus (560) introduces a new emphasising adverb: its stem is attested in the orators and in Hellenistic Greek, but like ékvouíws it seems to have been a colloquialism, comparable to English 'bloody'. ${ }^{79}$ Also, the threefold repetition of the strong assentient

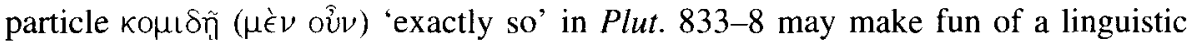

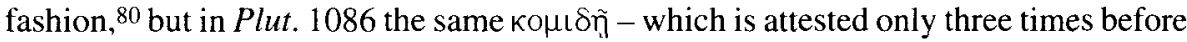
Plutus -, occurs without any stylistic distinction, just like the most ordinary everyday word. ${ }^{81}$

74 Ach. $4=1 / 308$ lines, Eq. $4=1 / 352$, Nub. $9=1 / 168$. Vesp. $12=1 / 128$, Pax $9=1 / 151$, Av. $9=1 / 196$, Lys. $12=1 / 110$, Thesm. $5=1 / 246$, Ran. $15=1 / 102$, Eccl. $7=1 / 169$, Plut. $19=1 / 64$; note again the break

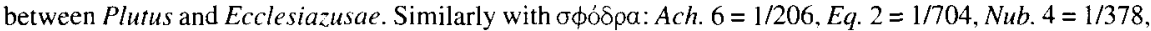
Vesp. $4=1 / 384$, Pax 0, Av. $2=1 / 883$, Lys. $1=1 / 1321$, Thesm. $4=1 / 308$, Ran. $3=1 / 511$, Eccl. $1=1 / 1183$, Plut. $7=1 / 173$. On the whole $\sigma \phi o ́ \delta p a$ is rarer than mávu, but the general tendency towards emphasis is nevertheless seen. Only the traditional $\mu a ́ \lambda \alpha$ is more frequent in $\operatorname{Pax}(8=1 / 171)$ and Lysistrata $(7=1 / 189)$ than in Plutus $(5=1 / 242$; cf. Ach. 0, Eq. $3=1 / 469$. Nub. $2=1 / 756$, Vesp. $1=1 / 1511$, Av. $2=1 / 883$, Thesm. $2=1 / 616$, Ran. $5=1 / 307, E c c l .1=1 / 1183)$. For the situation in other authors see Schwab $(1895)$ 179-84.

75 Plut. 17, 351,961, 1183; elsewhere: Eccl. 184 (in Praxagora's speech), Vesp. 478 (Bdelycleon). The only other occurrences in comedy are Pherecrates fr. 117 and Anaxandrides fr. 53.10. In classical prose, with the exception of Plato, Tò Tapá Tav is rare (cf. Schwab (1895) 187). Note the absence in Aristophanes of

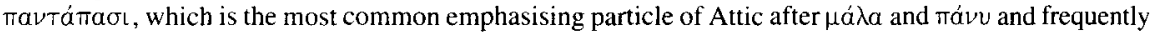
used by Xenophon, Plato, and Isocrates (though not yet by Thucydides and Lysias): cf. Schwab (1895) 183.

76 Plut. 445; nowhere else in Aristophanes. The addition of a preposition strengthens the emphasis also in $\dot{\epsilon} \pi^{\prime} \dot{\alpha} \lambda \eta \theta \epsilon i$ a for $\dot{\alpha} \lambda \eta \theta \omega \hat{s}$ (only in Plut. 891; cf. Holzinger (1940) 258).

77 Plut. 134, 328, 384 (oن̀ ä.; cf. Thesm. 442, female), Eccl. 281 (with verb of movement 'straight on', as in Lys. 609, 1069), 339; elsewhere: Eq. 63, 128 (both spoken by slaves), Av. 962, Ran. 741 (slave).

78 Plut. 981, 992 (used by the old woman and Chremylus): Ékvóulos is attested elsewhere only in Pind. Nem. 1.56 and Orph. fr. 121 .

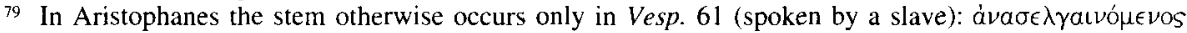
Eủpl $\pi i \delta n S$ 'Euripides wantonly abused'. Its etymology is unclear but a non-Attic origin is possible: cf.

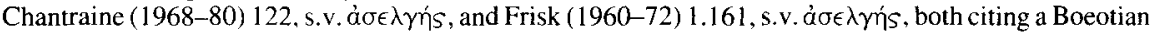

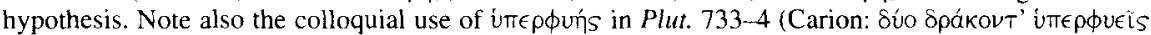

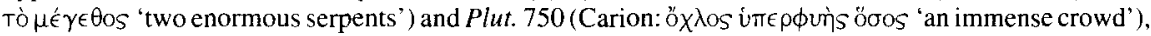
although this is shared with some of the earlier comedies (Ach. 142, Eq. 141. Nub. 76, Pax 229, Thesm. 831, Ran. 611, Eccl. 386).

80 Cf. Denniston (1954) lxvii and 88, and Ussher (1973) 184 on the repetition of yáp in Eccl. 773-6; see

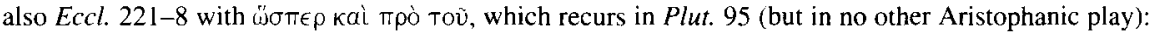
had it become usual to recall the good old times (cf. Holzinger (1940) 15-16)?

81 Earlier: Nub. 391 (Strepsiades), Pax 820 (Trygaeus), Thesm. 3 (Euripides' Inlaw); Ar. fr. 360, from Kúkaגos, is even later than Plutus. Among the other writers of Old Comedy only Pherecrates fr. 28 has

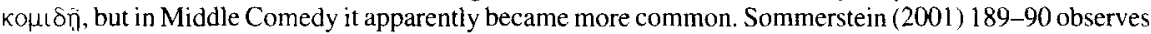
that Plato particularly associates the word with Theaetetus, one of his youngest dialogue characters. 
In the comparison of adjectives, emphasis also takes hold of morphology (cf. $\S 2.5$ ): only in Plutus do we read a superlative aùótatos 'his very self' (Plut. 83) and the

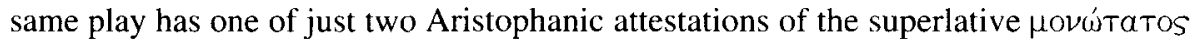
(Plut. 182; cf. Eq. 352). ${ }^{82}$

Perhaps more than anything on the preceding pages, this wealth of evidence for a new attitude towards pragmatic emphasis calls for a preliminary assessment. We might simply say that Attic Greek had changed. To some degree that must be true, but it cannot be the whole story, for it would leave unexplained why there is also a clear break between Ecclesiazusae and Plutus. It is counterintuitive to assume that 'real' language changed so much within four years. It is much more likely that, while 'real' language was changing gradually, Aristophanes' language changed quickly, and that Aristophanes was creating a new type of 'linguistic poetics'. With Plutus, Aristophanic comedy has become more colloquial, more mimetic or 'realistic' in the reproduction of everyday speech - at least if emphasis is plausibly attributed to common people's everyday speech. In order to demonstrate the plausibility of this we must now turn to a second set of pragmatic data which is ultimately connected to the first, 'emphatic', set, as will become clear immediately.

Like $\pi a ́ v v$, the adverb ö $v T \omega s$ 'really' is well-known: it occurs frequently in Plato, especially in the later dialogues. What is less known is the fact that ôvTWS represents another 'fourth-century-ism'. Thucydides does not use the word, and Aristophanes has it just four times in his fifth-century comedies and once more in Ecclesiazusae. Again, even this late play turns out to be written mainly in Aristophanes' old style as we realise that four years later, in Plutus, ővTws occurs no less than eight times. ${ }^{83}$ Moreover, the

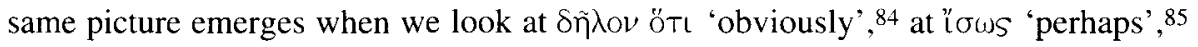
and at $\dot{\omega}$ "̈otke or other constructions based on the personal forms of "ैolka, to be rendered in English with 'apparently' or the like:86 these too are far more common in Plutus than in any other comedy. 87

82 A comparative aùtótє pos occurs in Epich. fr. 5: cf. Peppler (1918) 181-2 and Sommerstein (2001) 140, who improperly calls aùtótaтos a 'comic superlative'; there is a difference between colloquial intensi-

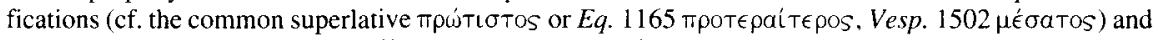
superlatives designed for comic effect (Ar. fr. 270 savaẃtatos 'Danaosest'). Note also that the intensifying comparison $\dot{\omega}$ s oủbeis ávmp is limited to the two last plays (Eccl. 1130, Plut. 247, 901: van Leeuwen (1904) xix).

${ }^{8} 3$ Plut. 82, 286, 289, 327, 403, 581, 836, 960; Nub. 86, 1271 (both times used by Strepsiades), Vesp. 997 (Philocleon), Ran. 1898 (Dionysus), Eccl. 786 (anonymous man); for examples in Middie and New Comedy (Antiphanes 3 exx., Menander 6 exx.) see Lautensach (1921) 252.

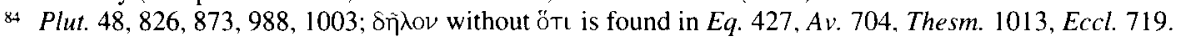

85 Plut. 158, 223, 259, 358, 423, 562, 896, 1012, 1058, 1067, 1080, perhaps also Plut. $148=11$ or 12 times (contrast the figures elsewhere: Ach. 1, Eq. 2, Nub. 3, Vesp. 7, Pax 2, Av. 0, Lys. 1, Thesm. 2, Ran. 4, Eccl. 4). The synonym táxa 'perhaps' is very rare: the only examples occur in lyric passages (Vesp. 277, 281, $1456, A v .453$ ) and the semantic distinction made by Schmidt (1876) 329-32 between tá $\chi \alpha$ and $1 \sigma \omega s$ is irrelevant for the situation in Aristophanes where the difference is one of register and where tá $\chi \alpha$ usually means 'quickly, forthwith'.

86 Plut. 76, 826, 862, 1017, 1040, 1045, 1048, 1098, 1131 = 9 times; in the other plays there are another 19 examples. The situation is less clear-cut with $\delta$ oKєi vel sim.

87 Add $\epsilon \hat{U} / \sigma a ́ \phi$ ' 8 times in the earlier plays (Ach. 783, Pax 373, 875, Av. 604, 1408, Thesm. 12, Ran. 296, 918). 
It appears, then, that Aristophanes' 'new characters' in Plutus qualify their utterances more often, sometimes by shyly adding 'apparently' or 'perhaps' and sometimes by adding 'obviously' with what at first sight looks like much selfconfidence. 'At first sight' because pragmatic studies on modern languages reveal that such apparent self-confidence only superficially conceals a speaker's greater uncertainty. To take a modern example, a speaker is often less certain about the menu plan when he/she announces 'obviously we are going to have potatoes for dinner' than when he/she says 'we are going to have potatoes for dinner': the former is likely to be a mere inference, made for instance on the basis of a smell from the kitchen, whereas the latter is an unconditional prediction appropriately pronounced by a host or chef de cuisine. In the terminology of semantics, it is usual to speak here of 'epistemic modality'. For John Lyons the 'fact of introducing must, necessarily, certainly, etc. [or, one may add, obviously, apparently, A.W.], into the utterance has the effect of making our commitment to the factuality of the proposition explicitly dependent upon our, perhaps, limited knowledge' .88

In fact, it is quite easy to demonstrate that $\delta \tilde{\eta} \lambda O V$ ÖTL is by no means more self-

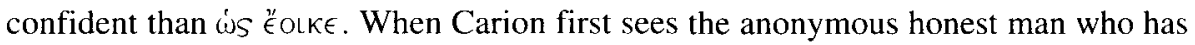
just become rich, he says (Plut. 826):

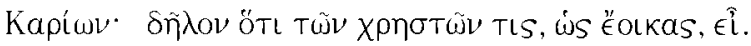

Carion: You seem plainly to be one of the good sort.

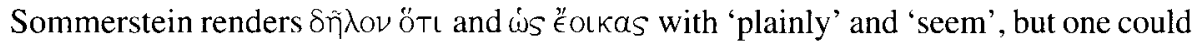
also opt for 'obviously' and 'apparently' if the resulting English were not so awkward: the general sense would be correct, despite the contradictory surface meaning of the two words. Of course, Carion will turn out to be right, but at this point the statement is nothing but his inference and he marks it as such. Despite the compliment, it might even be more arrogant if he said 'you are one of the good sort': he would then imply that he has the authority to act as a moral judge and not just to formulate a personal opinion. Thus, the more epistemic words such as 'obviously', 'apparently', etc. are used in a conversation, the more clearly do speakers 'individualise' their statements. To put it into a simplistic formula, Plutus shows a less apodictic world than all the previous comedies. ${ }^{89}$

88 Lyons (1977) 809. Of course there can be exceptions, but the fact that 'it is belief rather than knowledge which is usually to be assumed' in (not modalised) assertions (Palmer (1986) 87) does not imply that the form without 'obviously' etc. indicates the speaker's weaker commitment; the addition of 'obviously' makes the weakness (or relativity) of the commitment explicit.

89 Perhaps this reticence also accounts for the success of the colloquial indirect expression oux íy

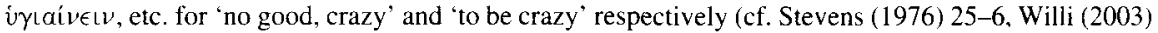
184-5, 190): the adjectival variant occurs 4 times elsewhere in Aristophanes (twice spoken by a woman: Thesm. 394. 636; male: Ach. 956, Eccl. 325) and 7 times in Plutus $(37,50,274,355,356,362,870)$, the verbal one 4 times elsewhere (female: $A v$. 1214; male: $N u b .1275$, Pax 95, Lys. 1228) and 4 times in Plufus $(364,507,1060,1066)$. In this context, the use of oùk äv $\phi \theta$ ávors + part. (e.g. Plut. 485 oủk àv

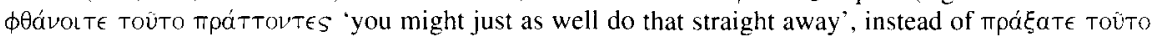


From here, we are led back to our earlier observation. By emphasising his or her words and phrases a speaker tries to give them the weight he or she feels they would not have without emphasis. The predilection for emphatic statements betrays the speakers' almost desperate struggle to be taken seriously. This kind of language, which suddenly becomes so common in Plutus, is not the kind of language 'big players' need to employ, but the language of those who are not listened to: the poor, the unimportant, those who know that the power of destiny is stronger than their resources. It is telling

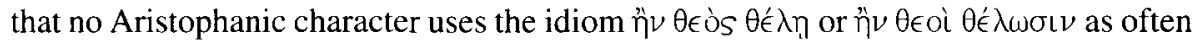
as Chremylus in Plutus. 90

Indirectly, the recognition that emphasis is omnipresent in Plutus also has an immediate impact on the interpretation of the play. It subverts one of the main arguments of those who read the play ironically and suggest that Aristophanes wants to show the pitfalls of universal wealth. According to this view, Chremylus' address to Plutus reveals the protagonist's dubious character (Plut. 230-3):

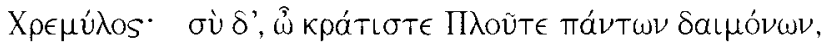

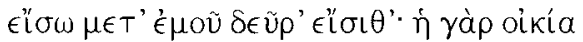

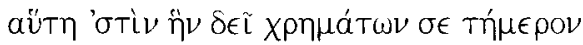

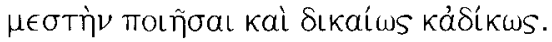

Chremylus: And now, Wealth, most powerful of all divinities, come inside here with me; because this is the house which today, by fair means or foul, you've got to fill full of good things.

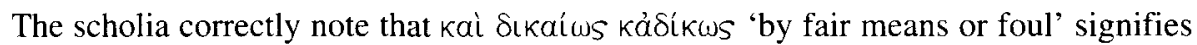

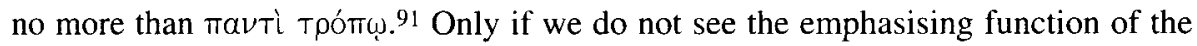
idiom are we tempted to take it literally, as if Chremylus was ready to proceed on an evil path if necessary. The absurdity of this conclusion is best revealed by a comparison with Andocides' Speech on the Mysteries (Myst. 1): no one would argue there, with exactly the same reasoning, that Andocides admits the legitimacy of (some of) his

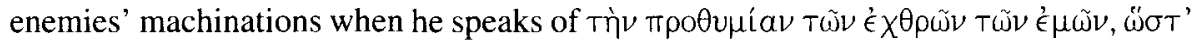

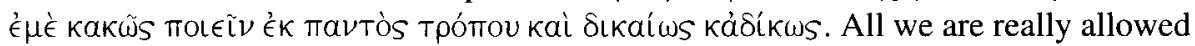
to read into the Aristophanic passage is Chremylus' subjective impression that he would not be listened to if he did not put all his verbal weight onto the scales and if he just

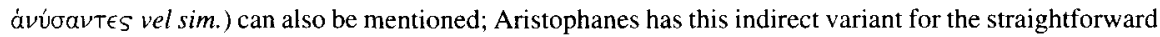
imperative (esp. the imperative + part. ávídas) only in Ecclesiazusae (118, female) and Plutus $(485,874$, 1133; cf. also Plut. 1102 where the inversion full verb + part. $\phi \theta a ́ \sigma a s$ instead of $\phi \theta a ́ v \omega+$ part. is analogical with the construction of ávú⿴囗⿱一一) ).

9) Plut. 347, 405, 1188; elsewhere the idiom occurs in Pax 939 and 1187 (chorus) and Ran. 533 (Xanthias).

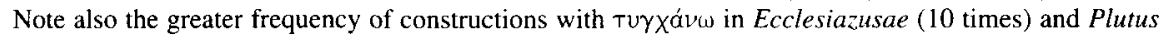
( 10 times; 33 times in the other plays): the importance of Túx $\eta$ in fourth-century mentality is well-known (cf. e.g. Hunter (1985) 141-4, Vogt-Spira (1992)).

91 Cf. Sommerstein (1984) 317, referring to Wilamowitz-Moellendorff (1909) 440-1. For the 'ironic' interpretation of this passage see Flashar (1975) 412-13 and cf. Radt (1976) 262 and Lévy (1997) 206. 


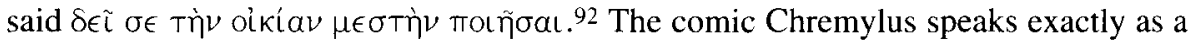
real Chremylus would speak - not surprisingly given the fact that 'in Ecclesiazusae and Plutus ... the category of status-defined figures expands to include certain of the main characters, who are invested with typical names, as for instance the slave Xanthias was in Frogs, and as now the old men Chremes and Blepyrus are in Ecclesiazusae and their counterpart Chremylus in Plutus' .93

\subsection{Morphology}

A morphological issue has already been touched upon when we noted the occurrence

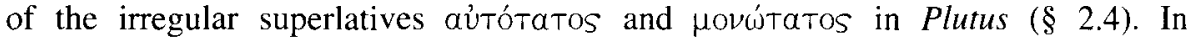
morphology, however, such specimens of emphasis are less important than the innovation manifesting itself in a trend towards analogical levelling. Not all examples are equally revealing, but taken together they show a remarkable coherence.

For instance, the first singular imperfect $\hat{\eta} v$ 'I was' of $\epsilon i \mu$ í is guaranteed only in Plutus ( 3 times); in all previous plays, the traditional form without final $-v$ is metrically possible $(\hat{\eta}<\hat{\eta} \alpha) .{ }^{94}$ Of course some actors may have used $\eta^{\hat{\eta}} v$ earlier on, but it was not compulsory. We even know that our distribution of $\hat{\eta}$ in the earlier plays and $\hat{\eta}^{\prime} v$ in Plutus must reach back to pre-medieval texts: otherwise it would make little sense for the Byzantine grammarian Choeroboscus to write that 'we have the usage $\eta^{j} \nu \dot{\epsilon} \gamma(\dot{\omega}$ with Aristophanes in Plutus, and with Menander in Georgos'.${ }^{95}$ The addition of the final $-\nu$ is an analogical process due to the presence of first-singular $-\nu$ in the regular imperfect paradigm.

Second, Plutus is also the only Aristophanic play displaying a thematic form of

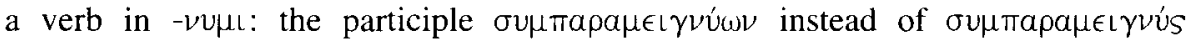
(Plut. 719). ${ }^{96}$ The fact that $\sigma v \nu$ - is a redundant preverb only intensifies the 'late' character of the participle: $\pi \alpha \rho a \mu \epsilon\llcorner\gamma \nu$ ú $\omega \nu$ would have been synonymous (cf. $\$ \S 2.3$

92 For similar reasons I am hesitant to follow Sommerstein (2001) 205 in his explanation of the unique

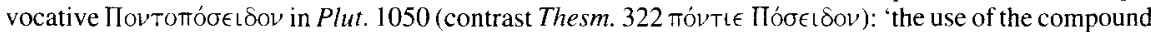

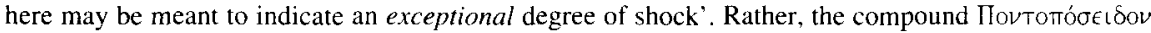
is as strong as a simple Пó $\epsilon t \delta o \nu$ used to be earlier on.

93 Silk (2000) 231.

94 Plut, 29,695, 822, each time with a following vowel.

95 Choeroboscus in Theodosii Alexandrini canones isagogicos de flexione verborum, p. 339.36-340.2

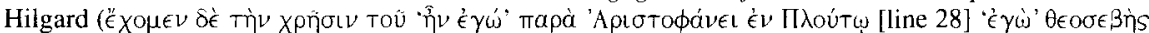

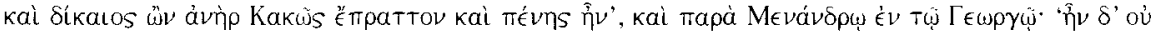

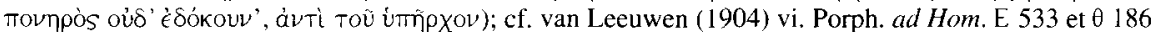
(quaest. Hom. ad ll. pert. p. 83.20 Schr.) cites for this गे only Cratinus fr. 194 among the comic poets, but since he is clearly selecting his examples this does not imply that he read $\eta^{2} v$ everywhere else in comedy.

96 Contrast especially Eq. 1399 and Ran. $944 \mu \epsilon \iota \gamma \nu u ́ s$. In Eq. $424 \dot{\alpha} \pi \dot{\omega} \mu \nu v o v$ is transmitted but metrically

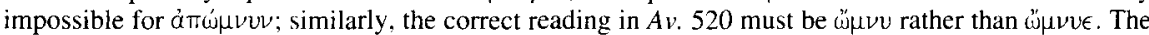
only other example in Old Comedy is Pherecrates fr. 152.9 (undated): for examples from Middle and New Comedy cf. La Roche (1893) 155-60 and Holzinger (1940) 222. According to Thumb (1901) 58-9. the origin of the thematisation must be sought in Ionic Greek. 
and 2.6). ${ }^{97}$ For the thematisation, analogical simplification is again the most straightfoward explanation.

Third, Plutus yields the best Aristophanic evidence for the pronominal neuter Tolovito without $-v$, instead of Toloütov. In order to read toloviov in Plut. 361 one would have to introduce a conjecture and to argue that the following interjection $\phi \in \hat{v}$ stands extra metrum. ${ }^{98}$ It is preferable to assume that analogy with Toúto was at work, as in later comedy.

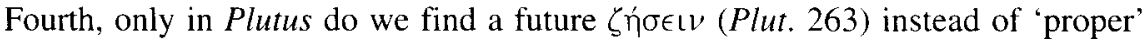
Attic $\beta t \omega ́ \sigma o \mu a t .{ }^{99}$ Similar forms are occasionally read elsewhere in fourth-century Attic. Herodotus, however, has an aorist $\ddot{E} \zeta \omega \sigma \alpha$ already in the fifth century, and in the Hippocratic corpus the middle future $\zeta$ '́ $\sigma$ o $\mu a \mathrm{l}$ is used. ${ }^{100}$ Perhaps, then, the analogical completion of the paradigm of $\zeta \tilde{\omega}$ 'to live' followed the footsteps of literary Ionic. Ionic influence must also be made responsible for the form $\ddot{\epsilon} \nu \in \kappa \in \nu$ instead of $\ddot{E} v \in \kappa a$ in Plut. 989,101 and possibly for the replacement of the genitive singular $-\epsilon \omega S$ of the $i$-stem úpls in Plut. 1044. The old woman complains:

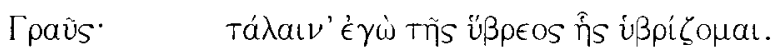

Old Woman: Poor me, the insults I have to endure!

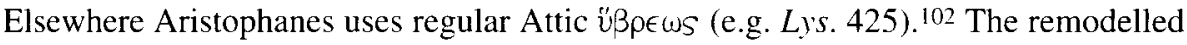
ending $-\epsilon O S$ was more in line with other genitives in $-O S$, and the existence of Ionic

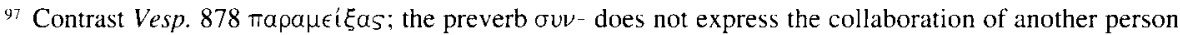

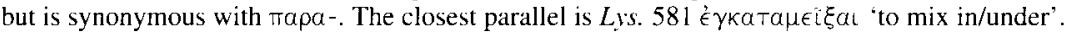

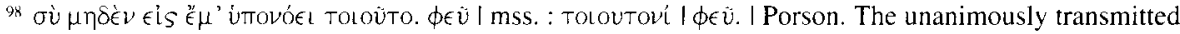
тобоن̈to in Eq. 1234 can be changed more easily into toбoùtov, although there, too, Toбov̀to may be correct since the speaker is the Paphlagonian slave with his lower-class style. In other cases -o is transmitted but metrically impossible: Pax 759 and Lys. 485. In Ran. 1399 both Tolovitov and Tolovito are transmitted and possible. In Plut. 897 Tolovtov is metrically ambiguous but transmitted with $-v$ (similarly Eq. 948, Nub. 832, Lys. 1225, Thesm. 747, Eccl. 394).

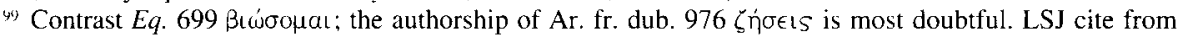
other Attic authors Pl. Rep. 465d (add Pl. Rep. 591c. Leg. 792e). Men. Mon. 186, from elsewhere also [Epich.] fr. 256.

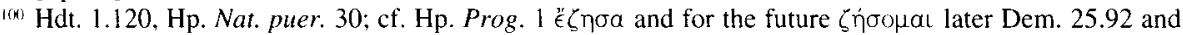
Arist. Pol. $1327 \mathrm{~b} 5$.

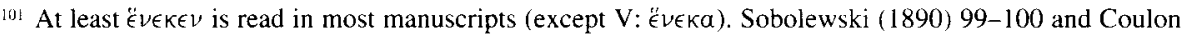
(1908) 32-5 excise $\tilde{\epsilon} v \in \kappa \epsilon \nu$ everywhere, but in the anapaests of $N u b .420$ and $E c c l .659-\epsilon \nu$ can be defended given the epic and tragic precedents. A separate explanation is needed only for the trimeter of Plut. 989

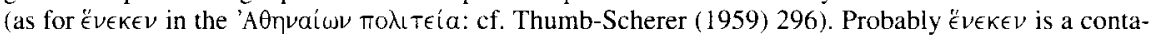
mination of Ionic $\epsilon$ IIV $\in \kappa \in V$ (nearly 30 times in Herodotus and a few times in the Hippocratic corpus: cf. Smyth (1894) 595-6) with Attic Ë $\nu \in K a$ and its absence on the Attic inscriptions until the end of the fourth century is due to the conservatism of epigraphic documents (cf. Thumb-Scherer (1959) 311). For other Aristophanic forms of this preposition (esp. oüveka) see Wackernagel (1887) 591-612 and Willi (2003) 234.

102 Outside iambic trimeters a genitive $\phi u ́ \sigma \in O S$ is transmitted in Vesp. 1282 (deleted by MacDowell (1971)

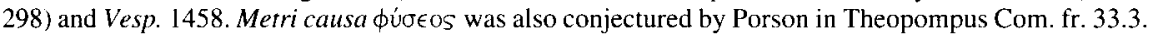

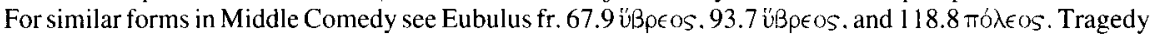

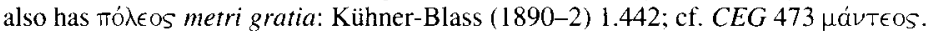


- $\operatorname{loS}$ (and occasionally - $\left.\epsilon_{O S}\right)^{103}$ may have made it even more attractive. De-Atticisation and analogy here go hand in hand.

Of course, all this morphological material does not amount to much when compared with the pragmatic data $(\S 2.4)$ or the lexical innovations to be discussed in the next section $(\$ 2.6)$. Even if two or three points were added, ${ }^{104}$ no more than a handful of lines would be at issue. However, since morphological innovations need much more time than lexical novelties to take roots, even five small indications add up to a relevant phenomenon if they point in the same direction, as they do in the present case.

What is the advantage of a morphological system regularised by analogy? Above all, such a system is more easily learned. This is the reason why children often create analogical forms until they are corrected by a 'monitoring community'. The same applies to adult learners, i.e. speakers who join a linguistic community from outside. Thus, a mixed and open society almost automatically develops a more regular morphological system than a closed society where all language learning takes place in early childhood and where conservative native speakers have enough influence to 'monitor' the language of the community members. ${ }^{105}$ As soon as this monitoring is reduced or falls away completely, the natural wish for regularity prevails: for a fluctuating society it is difficult (and not worthwhile) to prevent linguistic change. The analogical regularisations of Plutus may therefore parallel similar developments in the formation of international 'Koine' Greek: the highly traditional Attic of Old Comedy is yielding to a modern Attic influenced by and adapted for non-Athenians.

${ }^{103}$ See Thumb-Scherer (1959) 272 on Ionic tó́leos (already in $D G E 750$, Amorgos, 6th cent.; later: $D G E$

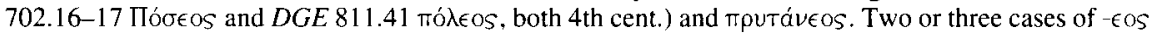
are found in the Attic inscriptions (esp. IG $\mathrm{II}^{2} 1749.76$ of $341 / 40 \mathrm{BC}$ with $\delta[1] a \delta \sigma^{\circ} \sigma \epsilon O S$, Threatte (1996) 213).

${ }^{104}$ (1) The optative of sigmatic aorists has two sets of endings in the 2nd and 3rd sg. and in the 3rd pl.:

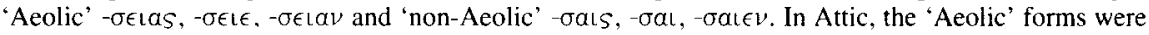

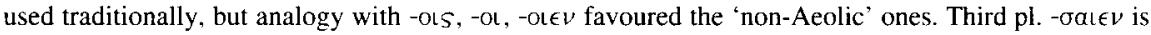

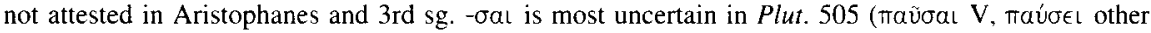

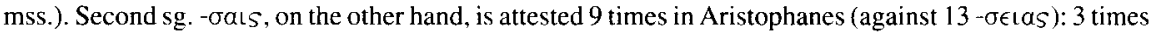
in anapaests where the form is poetic rather than innovative (Vesp. 572, 726, Lys. 506) and 2 out of the remaining 6 times in Plutus (Plut. 1036, 1134; cf. Nub. 776 Strepsiades, Pax 405 Hermes, Vesp. 819 Philocleon, Ar. fr. 332.15 from the second Thesmophoriazusae staged after $410 \mathrm{BC}$ ). Note that - $\sigma a \mathrm{~s}$ is more common than - $\sigma \epsilon \alpha_{S}$ in Middle and New Comedy: Lautensach (1917) 169-80, Willi (2003) 246. (2) Aristophanes uses a sigmatic aorist ě $\phi \theta$ a $\sigma a$ only in Plut. 685 and 1102 (against 5 times ë $\phi \theta \eta \nu$ in earlier plays including Ecclesiazusae) but in serious literature $\tilde{\epsilon} \phi \theta a \sigma \alpha$ is already attested in Herodotus,

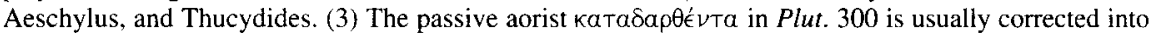

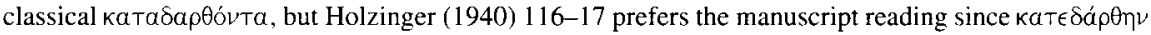
is attested in later Greek.

105 A vicious (or virtuous) circle is established when the regularity of a system ensures that more 'outsiders' are able to master it, but even then there is an interrelation between a language's grammatical 'simplicity' and its sociolinguistic success in a multicultural society. 


\subsection{Lexicon}

A further symptom of this transformation is the adoption of foreign words and phrases in the lexicon of Plutus. Because Attic and Ionic are closely related it is easier to uncover intruders from West Greek dialects. On the other hand, Ionic Greek influenced Attic much more deeply than these varieties. Nevertheless, there are occasional Dorisms which indicate that Athens was a melting-pot for visitors from all parts of Greece.

In Plutus three recent Dorisms can be identified. Two of them are interjections and thus form part of a lexical subgroup where foreign elements are integrated most easily. The first of these interjections is $\hat{\omega} \Delta \alpha \dot{\mu} \alpha \tau \epsilon \rho$, used by both Chremylus and Carion to express astonishment (Plut. 555, 872), but not occurring in any other Aristophanic play. ${ }^{106}$ Perhaps the connotation of Demeter as a mystery goddess gave the exclamation a comically solemn note, ${ }^{107}$ which was additionally strengthened by the Doric vocalism. ${ }^{108}$ In any case, shouting $\dot{\omega} \Delta \alpha{ }^{\prime} \mu \alpha \epsilon \rho$ must have been a usage imported from, or inspired by, other parts of the Greek world - for instance Sicily or Magna Graecia where the cult of Demeter and Kore was prominent. 109

The same conclusion is valid for the interjection $\pi \omega \dot{\mu} \mu \alpha \lambda \alpha$, which is approximately equivalent to oủ $\delta \mu \tilde{\omega} s$ or English 'why on earth, no way!'. There are two Aristophanic attestations: one in Plutus (66) and the other in Kúka入os, one of the two fragmentary comedies that post-date Plutus (Ar. fr. 361). ${ }^{110}$ Since the old ablative $\pi \tilde{\omega}$ was used in some Doric dialects as a synonym of Attic $\pi \theta_{\theta} \in \nu, 111 \pi \omega ́ \mu a \lambda a$ was obviously taken over from such a source; its pragmatic function is similar to that of mó $\theta \in v$ for "why?' 112 or with German ja woher! for 'no way, certainly not'.

The third new word that is neither Attic nor Ionic is the quasi-hapax lexeme $\sigma a ́ k T a s$ 'bag'. This is used by Carion in Plut. 681 although we should expect oákTms from a speaker of Attic. There can only be guesses as to why such a variant was introduced

106 According to Sommerstein (2001) 176, it "may be significant that both Chremylus here [i.e. at Plut. 555] and Carion there [at Plut. 872] are speaking in mocking tones', but this does not explain the Doric colour.

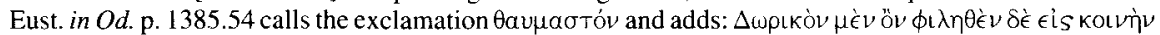

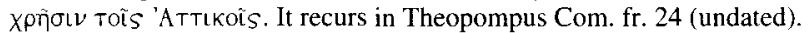

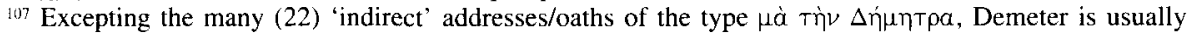
addressed as a mystery goddess in Aristophanes (cf. Ran. 385, 886; also Thesm. 286 with Demeter as $\theta \epsilon \sigma \mu \circ \phi o ́ p o s$ ). Early poetry makes Demeter the mother of Plutus (cf. Newiger (1957) 166, MacDowell (1995) 330) but this is irrelevant for Aristophanes' play, although there may be an Eleusinian element in the picture of Plutus (Sfyroeras (1995) 234-40, against Bowie (1993) 270).

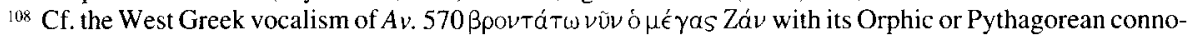
tations (Willi (2003) 102-3).

${ }_{1199}$ Cf. Headlam (1922) 29 and in general Zuntz (1971); see also the Sybarite woman's oath vaì tàv Kópav in Vesp. 1438 (where the context is Attic) and similar Doric oaths in Epicrates fr. 8.2-3, 10.7, and Plaut. Capt. 881.

110 See further Lys. fr. 254 S. $=110$ T., Dem. 19.51; in comedy only Pherecrates fr. 9 (of 420 BC).

111 Cf. e.g. Sophron fr. 121, Thumb-Kieckers (1932) 169, 217. Hesychius' information that Doric $\pi \tilde{\omega}$; also

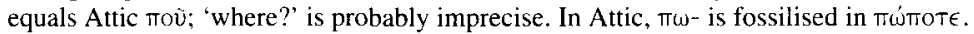

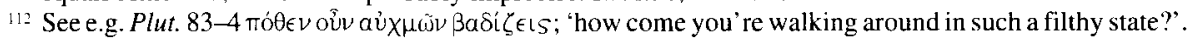


for an ordinary word like $\sigma a ́ k(\kappa)$ os. ${ }^{113}$ Since oákтas designates a storage item ${ }^{114}$ it may have been introduced by household slaves from Northern or Western territories, or by foreign merchants and slaves on ships where goods were stored in oákтal. Thus, it would have originated as a lower-class word, perhaps in the Attic of the Piraeus or similar places.

The sociolinguistic and pragmatic level of lexical imports from Ionia is different and they look less like colloquialisms, 115 as two examples will demonstrate. The first concerns the use of ÉvLOL and $\dot{\epsilon} \nu$ ít $\epsilon$ which, in Aristophanes, is limited to Plutus and to one probably late fragment. ${ }^{16}$ In Plut. $864-7$ the informer is outraged about the effects of Plutus' healing:

\begin{tabular}{|c|c|}
\hline$\sum u k \circ \phi a ́ v T \eta S^{\circ}$ & 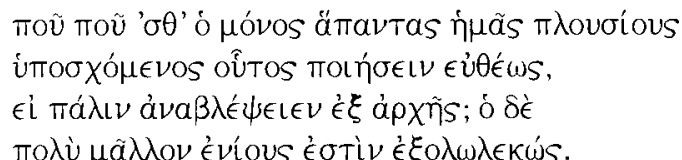 \\
\hline
\end{tabular}

Informer: Where is he, where is he, the one who promised that he'd make us all rich straight away, all by himself, if only he could recover his sight once again? What he'd done is much more like totally ruin some of us!

In earlier plays Aristophanes would simply have written Tuvás. The replacement of

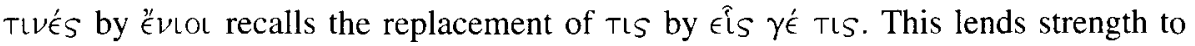
Wackernagel's etymology of évio as an adjective in $t$ tos from the numeral stem $\epsilon \mathcal{L}-$ of $\epsilon \hat{L} S$ 'one'. ${ }^{117}$ If the word originated in psilotic East Ionic, the absence of the rough breathing is unproblematic. In fact, prose (Thucydides, Antiphon, Andocides), but they are attested in Herodotus and more commonly in the Hippocratic corpus. ${ }^{118}$ In Attic literature only Eupolis and Euripides 'dared' to write eैvtot before the end of the fifth century, whereas

113 For бák( $\kappa$ )os in Aristophanes cf. Ach. 745, 822, Lys. 1211, Eccl. 502 ('bag' > 'beard'), and also Ar. fr. 343 бakíov, Lys. 824 бákavopos 'pubic hair' (cf. Henderson (1987) 173; for a similar development of бákтas see fr. com. adesp. 536). бákкos itself is a Semitic loan-word (cf. Chantraine (1968-80) 985, s.v.

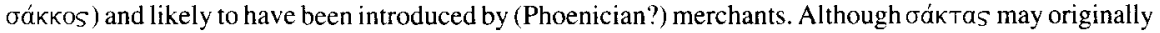

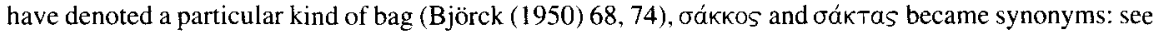
Pollux 3.155, 10.64 .

114 The origin of the Boeotian meaning 'doctor' (cf. Strattis fr. 49.5) remains obscure: perhaps 'celui qui

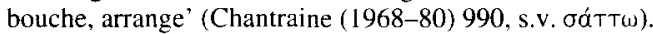

115 Admittedly, lower-class intrusions from Ionia would be more difficult to detect because Ionic words were more similar to Attic ones; literary loans, on the other hand, are recognisable since we can compare the distribution of any given lexeme in Ionic (Herodotus, Hippocratic corpus) and Attic writers respectively.

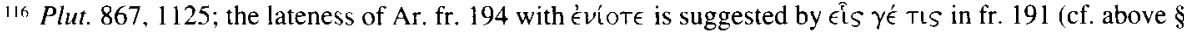
2.3).

117 Wackernagel (1907) $6 \mathrm{n}$. 1, following Benfey, against the traditional derivation of latter is implausible because ${ }^{\epsilon} \nu \imath=\dot{\epsilon} \sigma T i v$ is not attested before late Hellenistic Greek. For the formation

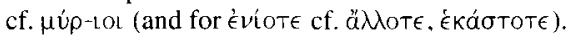

118 See Wackernagel (1907) $6 \mathrm{n}$. 1, with references. 
Aristophanes appears to have been impeded by his linguistic conservatism for another ten or twenty years. 119

The adverb 'Ełamiuns 'suddenly' is a second good candidate for new Ionic vocabulary in Plutus. Despite their surface similarity, the exact formal and etymo-

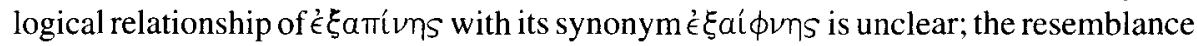
might even be secondary and result from the synonymy. ${ }^{120}$ Aristophanes normally uses

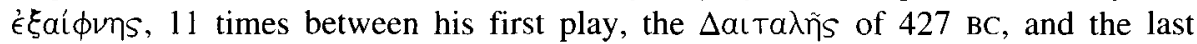
transmitted fifth-century play, Frogs. In Ecclesiazusae neither variant occurs, but in

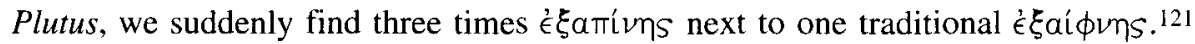
$\epsilon^{\prime} \xi \alpha \pi i v m s$ is absent from Attic tragedy and the prose of Plato, Demosthenes, and Isocrates. On the other hand, it does exist in Ionic and other poetry, ${ }^{122}$ in Herodotus, and again frequently in the Hippocratic treatises. We may therefore regard it as an Ionic loan-word adopted in fourth-century spoken Attic. 123

It would be possible to prolong the list of isolated lexical innovations in Plutus (cf.

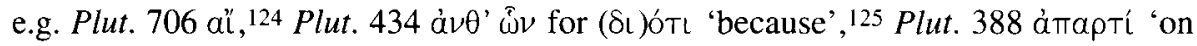
the contrary', 126 Plut. 1081 '́t Plutus and Ecclesiazusae 128 (cf. the frequency of colloquial $\mu \in \tilde{L} \rho \alpha \xi$ 'girl' 129 and the

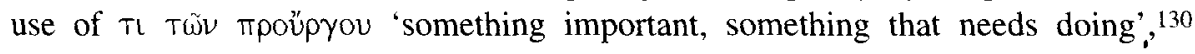

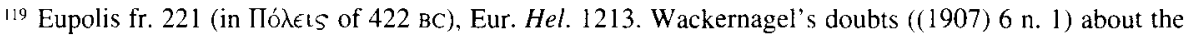

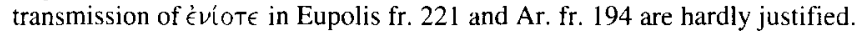

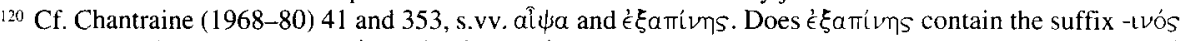

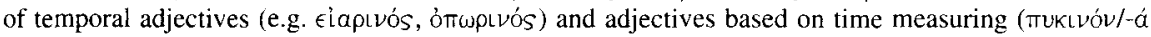

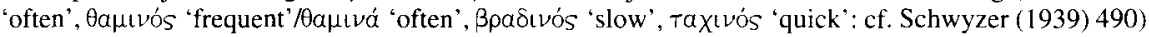
as would be plausible for a word meaning 'suddenly'? From a wrong segmentation of the distributive

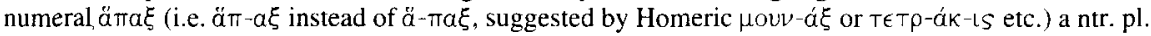

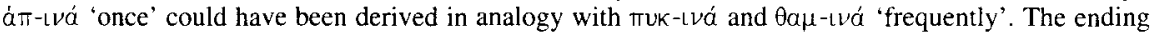

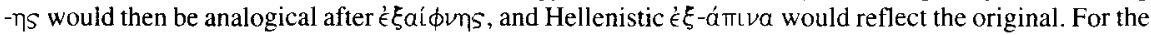
meaning English at once and German auf einmal 'suddenly' could be compared.

${ }_{121}$ Plut. 336, 339. 815 vs. Plut. 353. The occurrence in $\Delta a \operatorname{ta\lambda } \eta \bar{s}$ is Ar. fr. 237.

122 For instance in Homer (Il. 5.91, 9.6, etc.), Alcaeus (fr. 298.27 V.), and Pindar (Pyth. 4.273).

123 Sophocles has $7 \dot{\epsilon} \xi a i \phi \nu \eta s: 0 \dot{\xi} \xi a \pi i v \eta s$; Euripides $4: 0$; Plato $36: 0$; Demosthenes $13: 0$ ( $\dot{\xi} \xi a m i ́ v \eta S$ occurs once in the spurious $\operatorname{Or}$. 59); Isocrates $2: 0$; Herodotus $0-1$ (very uncertain: Hdt. 9.45.3) : 2; Hippocratic corpus $58: 88$; Thucydides $7: 6$ (perhaps influenced by Ionic historiography); Xenophon $17: 8$; Menander $7: 4$.

$12+$ The (typically female: Bain (1984) 35-6) interjection ai becomes common only in Menander (Sommerstein (2001) 183) whereas doubled aiaĩ occurs earlier, usually in paratragic contexts (Ach. 1083-4, Thesm. 885, 1042, Lys. 961 ) unless spoken by women (Lys. 393, Eccl. 911 ).

${ }^{125}$ As in later Greek: cf. Schwyzer-Debrunner (1950) 661.

126 Cf. elsewhere in comedy Pherecrates fr. 77 and fr. 98, Pl. Com. fr. 59, and (as in Herodotus) with a meaning 'completely' Eupolis fr. 429.

127 As in Xen. Anab. 6.5.11 and in later Greek; however, Sommerstein (2001) 207 doubts that Plut. 1081 has been correctly transmitted.

${ }^{128}$ Cf. van Leeuwen (1904) xix-xx.

${ }^{129}$ The colloquial character of $\mu \in i \rho a \xi$ is shown by the suffix (Chantraine (1968-80) 678, s.v. $\mu \in i \rho p \xi$ ). Five occurrences in the fourth-century plays (Eccl.611,696, 1138, Plut. 1071, 1079) stand against one earlier example (Thesm. 410, female); cf. also Cratinus fr. 60 and fr. 334. $\mu \epsilon\llcorner$ Lкi $\sigma \kappa \eta$, too, occurs rather late (Ran. 409, Plut. 963) but $\mu \in \mathrm{t}$ áktov is common throughout Aristophanes' plays.

${ }^{130}$ Eccl. 784, Plut. 623. For Tpoüpyou cf. also the comparative in Lys. 20 (female speaker) and occasional occurrences in Thucydides, but most examples occur in fourth-century texts. 


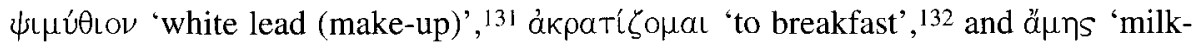
cake'). ${ }^{133}$ More interesting, however, is the discussion of three more general points.

The first of these ties in with our earlier observations on syntactic redundancy. The

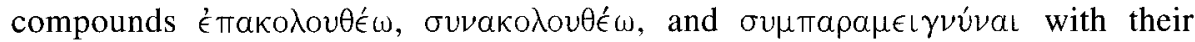
redundant preverbs $\dot{\epsilon} \pi L-$ and $\sigma v \nu$ - have already been mentioned ( $\$ \S 2.3$ and 2.5 ). Now,

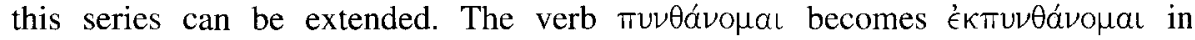

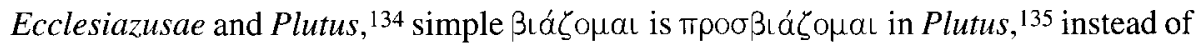

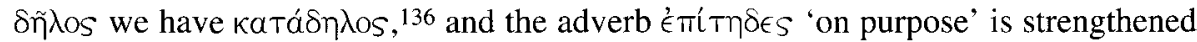
into $\dot{\epsilon} \xi \in \pi i T \eta \delta \in S .137$ The reason for these remodellings is the same as before: semantic weakening is counterbalanced by emphatic redundancy. Thus, the lexical data completes the picture sketched in the sections on syntax and pragmatics ( $\$ \S 2.3$ and 2.4).

A second general point concerns linguistic fashions. The innovative words cited so far will already have made it clear that some lexical changes advance our understanding of the sociolinguistic environment of the play more than others. If we see that kó $\mu$ ios

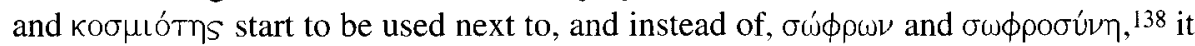
is difficult to relate this to a wider context. Once in our play we even find an explicit remark on such 'random' lexical change. Chremylus addresses the chorus of fellowdemesmen who have come to share in his riches (Plut. 322-5):

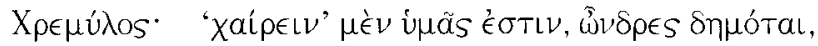

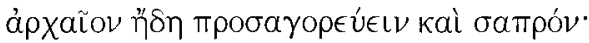

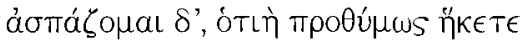

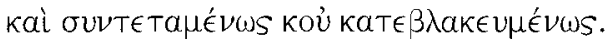

${ }^{131}$ Eccl. 878, 929, 1072, Plut. 1064; also in fr. 332 of Thesmophoriazusae II (undated) and in Plato, Xenophon, Amipsias fr. 3.

132 Plut. 295; also in Ar. fr. 621 (undated)

133 Plut. 999; also in Middle and New Comedy.

134 Eccl. 752 ('perhaps here the prefix should be stressed, "make full inquiries"', Ussher (1973) 182), Plut.

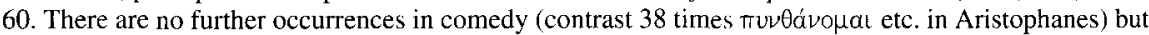
the compound occurs in tragedy; tragic redundancy is ridiculed in Ar. Ran. 1152-79.

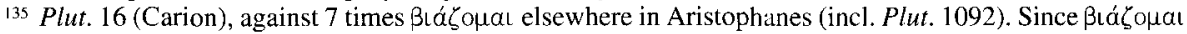

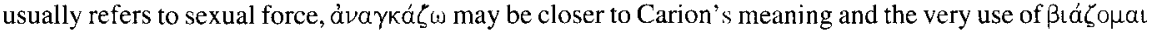
reveals the search for stronger expressions. Note also that 2 out of 3 Aristophanic examples of

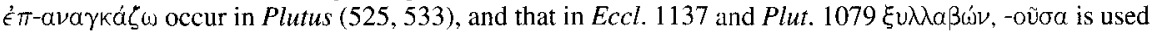
in the sense of simple $\lambda \alpha \beta \omega$ ' $v$ (ä $\gamma \omega \nu$ ) 'taking along (of a person)' (not: 'collecting, assisting, arresting, etc.'; cf. elsewhere in Aristophanes only Vesp. 122, spoken by a slave).

136 Plut. 1065 (Chremylus); elsewhere in Aristophanes 25 times $\delta$ ๆ̃ 0 os (6 times in Plutus).

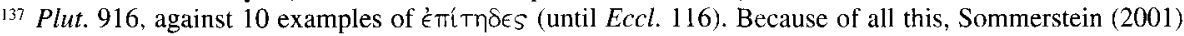

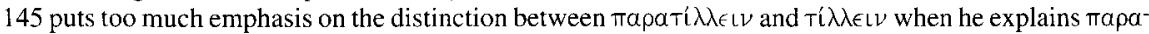

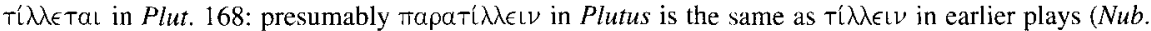
1083, Thesm. 543).

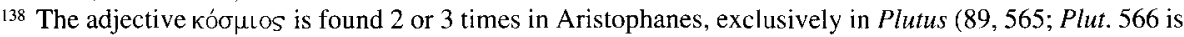

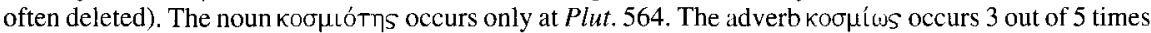
in Plutus (Plut. 671, 709, 978) and twice more in a woman's line of Thesmophoriazusae (573, 853; cf.

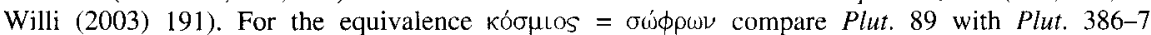
(Sommerstein (2001) 176). 
Chremylus: To greet you with 'good day', my fellow-demesmen, is old-fashioned and past it now. So, a warm welcome to you for having come so eagerly, so energetically and so unslothfully.

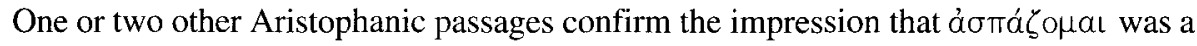

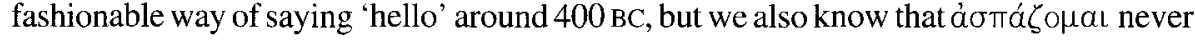

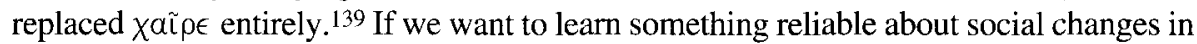
the world of Plutus we must refrain from (over-)interpreting short-lived linguistic fads.

Even so, the third and last general point shows that there are areas where such efforts to elucidate the interrelation of lexical and social changes can prove worthwhile. The term $\kappa \in \kappa T \eta \mu \epsilon ́ \nu O S$ for 'master', which was chastised by the more severe atticists, ${ }^{140}$ is attested only in Aristophanes' two fourth-century comedies; ${ }^{141}$ earlier on, the same concept is always (and frequently) denoted by $\delta \epsilon \sigma \pi o ́ t \eta s .{ }^{142}$ Apparently, a master-slave focus is given up in favour of an owner-slave focus. Thus, the crucial factor to determine a man's status has become economic rather than social: his wealth and possessions count more than his birth and origin. Carion, for instance, mentions that he became a slave out of debts, and there is nothing to suggest that the audience should be surprised to hear this even though debt-slavery of Athenians had been abolished since the time of Solon (Plut. 147-8):143

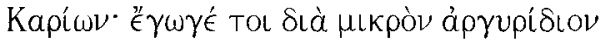

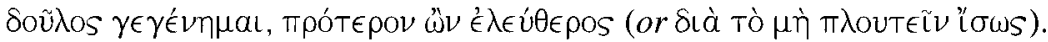

Carion: I certainly became a slave because of a petty little sum of money, having previously been free (or perhaps because of not being rich).

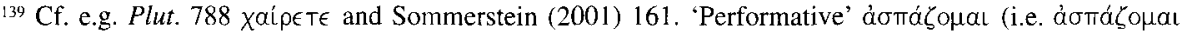
$(\sigma \in / i \mu \tilde{s})$ in the $1 \mathrm{st} \mathrm{sg}$. or 1st pl. used to address people) recurs in Plut. 1042 where the young man ironically addresses the old woman. In earlier comedies it is found in $N u b .1145$ with the modernist Socrates and in $A v .1377$ where Peisetaerus greets the poet Cinesias in Cinesias' own exalted style. The tragic use of $\dot{\alpha} \sigma \pi \dot{\zeta} \zeta o \mu a t$ reveals its stylistic level (cf. paratragic/elevated passages like Alexis fr. 172.5, Men. fr. 1, and Ar. fr. dub. 965): Eur. Ion 1363 and perhaps Soph. fr. 602.l come closest to a 'performative'

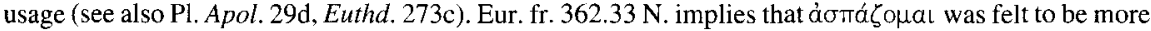
emotional than simple $\chi a i ̃ \rho \epsilon$. Non-performative $\alpha \sigma \pi \alpha \dot{\zeta} \epsilon \sigma \theta a \iota$ 'to greet (esp. with kisses or an embrace)' is common at all times (e.g. Ar. Vesp. 607, Pax 559, Eccl. 971, 975, Plut. 743, 752). In Hellenistic and

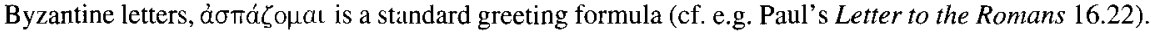

${ }^{140}$ Cf. Antiatticista p. 102.20-1 Bekker; $\kappa \epsilon \kappa T \eta \mu \epsilon ́ v 0 s$ occurs for instance in Menander, but also in Xen. Oec. 20.22, Pl. Leg. 882b, and already in Phrynichus Com. fr. 50.

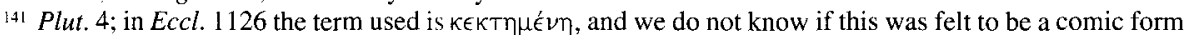
like knpúkaıv $\alpha$ and $\sigma \tau \rho \alpha T \eta \gamma$ 's in the same play $(E c c l .713,835)$ or a normal 'slave's way of referring to

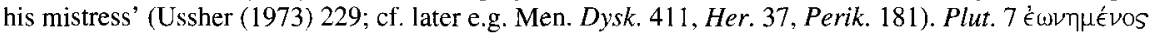
can be added here because the underlying concept is the same. In Soph. fr. $762\lceil\kappa \epsilon \kappa T \eta \mu \epsilon \ln \eta$ refers to ownership of animals and Pearson (1917) 17 points out that, for 'mistress', 'tragedy elsewhere uses in

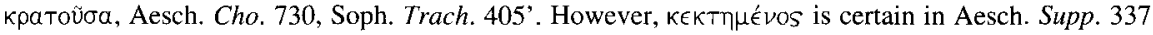
and Eur. $I A 715$ ('master' = 'husband') though perhaps meant to shock the audience.

${ }_{142} \Delta \epsilon \sigma \pi \delta ́ T \eta \bar{s}$ occurs more than 70 times in Aristophanes (16 times in Plutus); $\delta \epsilon \sigma \pi o l v \alpha$, too, is very common.

${ }^{143}$ For the existence of debt-slavery and debt-bondage outside Athens see Sommerstein (2001) 142-3. Aristophanes by no means had to refer to Carion's original status. 
On an ideological level it may at first sight seem more liberal to see in a $\delta \epsilon \sigma \pi o ́ T \eta S$ not a better man but just a richer one, and perhaps this 'liberalisation' allowed the comic poets to invent leading characters like Carion (although this might also be due to the wish to retain some 'roguish' elements in a 'softer' comedy). 144 On the other hand, though, the real status of slaves as mere possessions also became more explicit this way. ${ }^{145}$ The agon of Plutus presents a telling example of how little attention could be paid to the human nature of slaves. When Penia asks Chremylus who is going to do the hard work when all men have become rich, Chremylus replies that everyone will simply buy slaves. Now, Penia does not counter this idea with what might constitute a straightforward argument: that slaves, too, should become rich and free. Instead, she makes a logistic point: no one will supply slaves any longer (Plut. 510-26).

Of course, to read a change from a social to an economic mentality into a single lexeme ${ }^{146}$ means putting much weight on little linguistic evidence. However, there is a further issue that points in the same direction. No part of the lexicon of a language reveals as much about mentality as a language's terms of abuse: they betray where the taboos of a society are.

That Tol $\chi \omega \rho$ úxos 'burglar' occurs six times in Plutus and only three times in all the other comedies at first looks natural given the theme of Aristophanes' last play. ${ }^{147}$ Yet, in four of these six attestations, the meaning of Tol $\chi \omega \rho \cup$ ú $O S$ is not 'burglar' but unspecifically 'villain, crook'. In the earlier plays, Toเ $\chi \omega \rho \cup$ úS had been used in this way, as a general term of abuse, only by the rustic Strepsiades in Clouds and by the slave Xanthias in Frogs. ${ }^{148}$

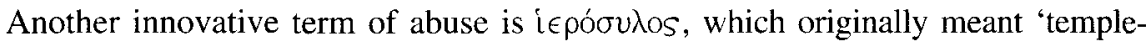
robber', but which came to be used, in various fourth-century authors, in the same generic

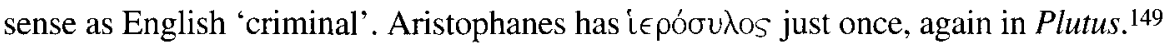

144 Cf. Dover (1972) 207-8; Sommerstein (2001) 138 stresses the impertinence of Carion's address to his

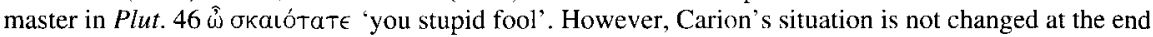
of the play and it is only 'from the master's point of view ... that the social structure of Wealth's new world is a marked improvement over the old' (Olson (1989) 199).

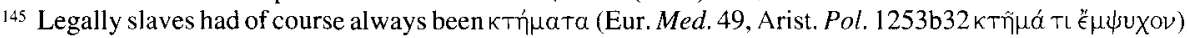
and enjoyed very limited rights only (e.g. that of not being killed by the owner: cf. MacDowell (1978) 80 ).

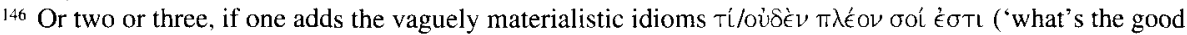

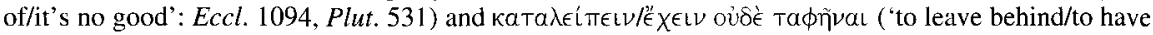
not even enough to pay for one's funeral': Eccl. 592, Plut. 556), which are attested only in the last two plays (van Leeuwen (1904) xix).

147 Cf. Pl. Leg. 831c-e, where burglary and temple-robbery are seen as results of lust for wealth. The frequency

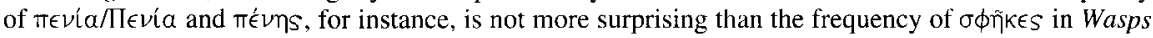

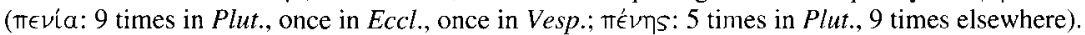

${ }_{148}$ Nub. 1327, Ran. 808, Plut. 869 (Carion), 909 (honest man), 939, 1141 (both Carion). The original meaning is preserved in Ran. 773 (slave), Plut. 204 (Plutus), and (verbally) Plut. 165 (Carion). Elsewhere Tor $\chi \omega$ úx ${ }^{\circ}$ os occurs as a general term of abuse, e.g. in Amipsias fr. 23 (undated), Dem. 35.9, and Diphilus fr. 3 (applied to an object).

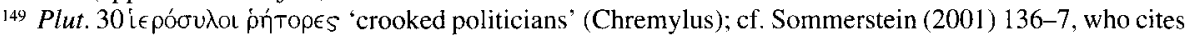
as parallels Men. Dysk. 640, Epitr. 952, 1064, 1100, Perik. 366, Lys. 30.21, and Eubulus fr. 6.4 (applied to an object). In Vesp. 845 the verb i $\epsilon$ poov $\lambda \hat{\epsilon}^{\prime} \omega$ is used literally for 'temple-robbing'. 
If we thus find two new terms of abuse borrowed from the sphere of robbing and thieving, ${ }^{150}$ we may legitimately conclude that the taboo-status of breaking property rights had become stronger and threatened the primacy of social offences like

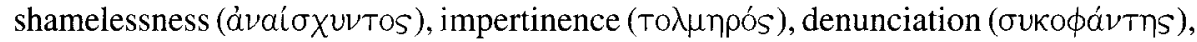

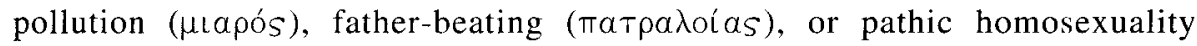

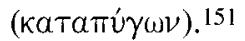

Finally, to conclude on a different and even less respectable note, this loss of interest

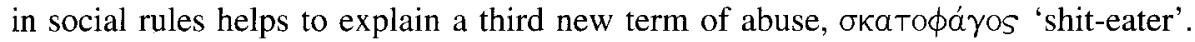
Dover has recently observed that Aristophanes 'abstains from the use of "basic" [i.e. heterosexual and scatological in contrast to homosexual, A.W.] obscene metaphor in reproaching stupidity and unpleasantness'. ${ }^{152}$ In fact, Plut. 706, where Carion shockingly 153 calls the god Asclepius $\sigma \kappa a T o \phi a ́ \gamma o s$, is the only exception. Since socially established taboos like pathic homosexuality presuppose a cohesive social framework, a 'functioning society', the loss of such an environment may favour the linguistic exploitation of 'natural' taboos (like the eating of excrement) which are controlled by each individual in his or her own interest. ${ }^{154}$ I would therefore suggest that the abusive lexicon of Plutus mirrors a 'change of scenery', a turn away from the world of the community and a turn towards the private sphere of personal rights and wrongs.

${ }^{150}$ Of course, $i \epsilon \rho \circ \sigma v \lambda i a$ is also a religious offence but unlike $\mu i \alpha \sigma \mu \alpha$ it operates on an economic level.

${ }^{151}$ For these and other terms of abuse in Aristophanes see now Dover (2002). Some of them are not found

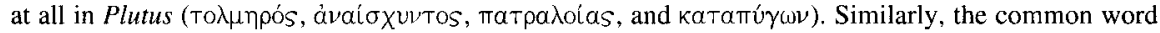
Tavoũpros is as rare as in later comedy (only Plut. 37 ; cf. Menander with only 5 exx.): contrast for instance

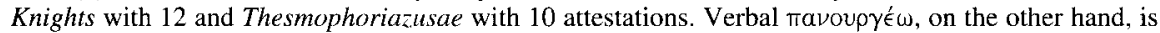
rare before Plutus (Ach. 658, Eq. 803, Nub. 1309, Thesm. 893), but occurs 3 times there (Plut. 368, 876, 1145). The reason is probably the increasing use of compound verbs in - $\epsilon \omega$ in fourth-century Greek (cf. Sütterlin (1891) 63, Debrunner (1917) 95, Willi (2003) 122-6).

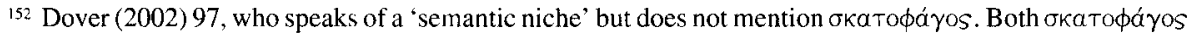

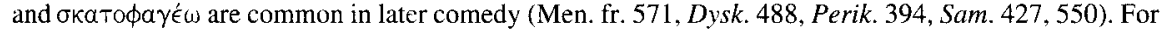

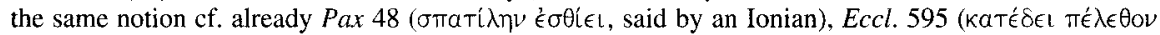

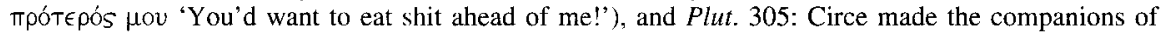

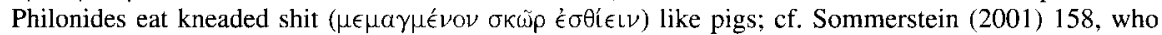

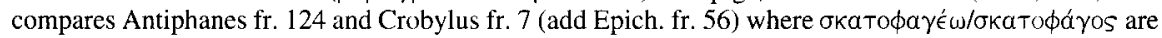
used literally, as vulgar but not abusive terms.

153 Cf. Henderson (1991) 192; the word is introduced climactically after Chremylus' wife has used the mildly abusive term ă $\gamma$ polkos (Plut. 705).

${ }^{154}$ To explain the 'semantic niche' in this way is probably preferable to assuming that oral and anal sexual practices were 'more taboo' than excremental phenomena and therefore potentially more abusive (Willi (2002) 10). $\Sigma \kappa(\tilde{\rho} \rho$ 'shit' itself may have been a taboo word before the late fifth century; being an IndoEuropean collective noun like $\tilde{\delta} \omega \omega$, it must be very old although it is not attested before Ran. 146 (Heracles), Plut. 305 (Carion), Sophron fr. 11, and Strattis fr. 8 (where the source claims that Ran. 146 is the first occurrence). 


\section{New language for a new comedy: summary and conclusion}

The features and changes that have been listed and discussed in the preceding sections bear testimony to three comprehensive innovative trends in the language of Aristophanes' Plutus:

(1) A trend towards a more colloquial and sometimes distinctly lower-class style is perceived, above all, on the syntactic and pragmatic levels ( $\$ \S 2.3$ and 2.4 : semantic weakening and redundancy, emphasis and epistemic modality), supplemented by one phonological point $(\S 2.1)$.

(2) A loss of 'Atticness' and an increase of foreign, especially Ionic, elements is seen in the gradual disappearance of the dual and of otros beside iva $(\$ 2.3)$, in the new

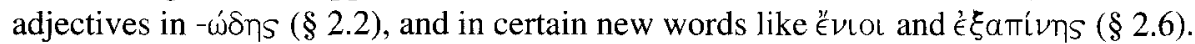
Probably the morphological trend towards analogy also belongs in the wider context of this 'internationalisation' of Aristophanes' Attic ( $\$ 2.5)$.

(3) A partial restructuring of the lexicon reflects ongoing social changes, a replacement of social interests and concerns by individual ones and a new economic mentality which presumably resulted from an 'across-the-board decrease in fortunes' in the early fourth century ${ }^{155}$ and led to growing tensions between the rich and the poor $(\S 2.6) .{ }^{156}$

It is easy to see the link between all three developments since the linguistic analysis mainly corroborates what is already known about the novelty of Plutus as a literary text. With the disastrous defeat in the Peloponnesian War, Athens had lost not only her empire but also her pride. Even though some form of cultural leadership remained the city's prerogative, this was no longer the cultural leadership of the Athenian polis, but rather a cultural leadership of certain Athenian individuals. Whereas Aeschylus and Sophocles had written tragedies to teach the polis, Plato was now writing dialogues to teach the individual, and whereas Pericles had addressed the Athenian as an Athenian, Isocrates was now addressing the Athenian as a Greek.

There are limits to such generalisations and it is certainly true that 'the reasons why comedy ceased to perform the function of rebellion in fantasy against the publicly accepted ideal of good citizenship ... must not be sought solely in political and social history without reference to the autonomous development of comedy as an artistic genre'. ${ }^{157}$ Nevertheless, the generalisations also contain some truth, and no literary

i55 Dillon (1987) 162; cf. Plut. 130-97, David (1984) 32-8, and Ehrenberg (1951) 238 = (1968) 240-2: 'All these passages prove that financial questions came to be of ever-increasing importance in both public and private life. This would not have been the case if economics in general had not taken hold of the minds of almost the whole people and even influenced ethics and religion.'

${ }^{156}$ See David (1984) 19, who illustrates this with speeches from the Lysianic corpus (Lys. 22.15, 22.20; 27.10-11).

157 Dover (1974) 301. 
genre mirrors the political and social, as well as mental, 'revolution' more clearly than comedy - as has been acknowledged since antiquity. With the end of the great war, political comedy, 'Old Comedy', has lost its fertile soil and 'Middle Comedy', hovering between parody of myth ${ }^{158}$ and the domestic world of cooks, slaves, and hetairai, takes over the stage. In Ecclesiazusae a political theme is still at the heart of the play when the poet asks how the state should be organised, ${ }^{159}$ but in Plutus the style of Old Comedy is retained only in a few formal reminiscences such as the (limited) existence of an integrated chorus, the anapaestic agon, and the episode series in the second half of the play; ${ }^{160}$ politics, however, has virtually disappeared and the distribution of wealth is represented not so much as a social problem, but as the problem of every (good) individual - a far cry from the communism of Ecclesiazusae, to which everyone must contribute his or her share. Admittedly, Plut. 1191-5 briefly mentions that Plutus is going to be (re-)installed in the treasury located in the temple of Athena on the acropolis, but Bowie rightly notes that this remark 'receives curiously less emphasis than the induction into Chremylus' house'. ${ }^{161}$

After the defeat of $404 \mathrm{BC}$, and during the unlucky years of the Corinthian war, 162 the polis Athens could no longer serve as a glorified reference-point for the self-identification of its citizens: being Athenian gradually came to mean being a loser. In this situation, it was distinctly unattractive to maintain the symbols of the past and, by implication, to defend traditional language against the attacks and demands of the present new world, which had been internationalised not least by the same unfortunate wars. Similarly, there was no longer much point in getting involved with the communal life of a polis whose desperate struggle to regain its former greatness was patently unsuccessful. As Dillon points out, the loss of importance of 'political' (in the sense of

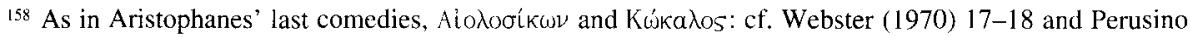

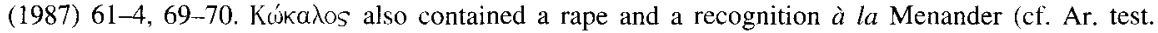
$1.49-51)$.

${ }^{159}$ See especially Praxagora's programme (Eccl. 583-688) and the war theme of the speech rehearsed in Eccl. 170-240 (esp. Eccl. 193-203, 233-4): 'Old Comedy makes its last brilliant bow in the Ekklesiazousai and the curtain goes up on mythological comedy in the Ploutos' (Webster (1970) 36).

160 Nesselrath (1990) 334; this is hardly sufficient to make Plutus the "last representative of Old (or better: Aristophanic) Comedy' (Dillon (1985) 215, cited by Nesselrath (1990) 337 n. 8; cf. also Sfyroeras (1995) 253, who detects metatheatrical reflection reminiscent of Old Comedy). The boundary between Old and Middle Comedy is more distinct than that between Middle and New Comedy (cf. Nesselrath (1990) 337, citing Landfester (1979) 354).

${ }^{161}$ Bowie (1993) 290. Attica is also referred to in Plut. 772-3, but note that Penia will be thrown out of Greece (not Athens) according to Plut. 463. McGlew (1997) 47-52 pays too little attention to this when he reads the play as a call for Athenian reunification.

162 For the problematic situation of Athens around 390 BC ef. David (1984) 33-4 and Sommerstein (2001) 1-4: in 389 an expedition to besiege Aegina was unsuccessful, in 388 the hopes for Persian support faded away, and in 387 Athens had to accept an unconditional peace dictated by Persia. The general feeling of hopelessness (underestimated by Dillon (1987) 157-8) is reflected in Lys. 28.15, of 389 BC (KaíTor

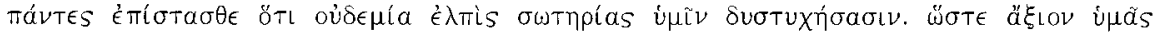

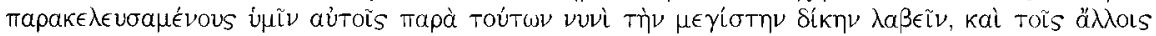

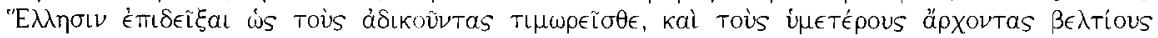

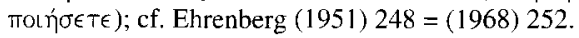


social and communal) structures concretely manifests itself also outside comedy: for instance, in the necessity of introducing payment for assembly attendance, in the professionalisation of speech-writing, in the increasing use of mercenary troops, in a professionalisation of the civil service, and in the invention of private 'euergetism'; 163 perhaps one may add the abolition of radical democracy in 403/2, which meant that the powers of the people's assembly were reduced: 'legislation and jurisdiction came to be the monopoly of the 6,000 persons each year who had sworn the Heliastic Oath, who served partly as nomothetai (legislators), and partly as dikastai (jurors)'. ${ }^{164}$ Even though most Athenians remained potential decision-makers in the socio-political sphere, other - by implication more private or 'individual' - interests would now come to dominate the daily agenda.

Being a keen observer of society, Aristophanes could not fail to notice these developments. As he had always identified himself with the role as a teacher of the polis, they must have hit him hard. In this brave new world, teaching the polis was no longer a real option. Instead, there was a choice between two possibilities. Either, the comic poet could proceed as if nothing had happened and as if comedy still had to bite people like Cleon - although such people had disappeared together with the political and social environment upon which they had relied. To some degree and with some success, this is what Aristophanes tried to do in Ecclesiazusae. Or else, the comic poet could (re)invent a new type of comedy: again of course a comedy for the people (for there could not be another kind of comedy), but no longer a comedy for the Athenian people, the demos. Aristophanes' Plutus is precisely such a 'new' comedy for the people tout court. ${ }^{165}$ If this seems dull to us, it need not have seemed so to an ancient audience who had grown tired of tradition and traditions.

Even today, however, Plutus deserves some credit, and this is above all due to its new language. The symbiotic unity of theme and words is as perfect as ever, for here too Aristophanes was facing a choice between two options. Either, he could adopt the language which he had always used and brought to perfection: a purely Athenian, conservative polis discourse regulated by its own poetics of humour, a Kunstsprache which the anonymous author of the Prolegomena de

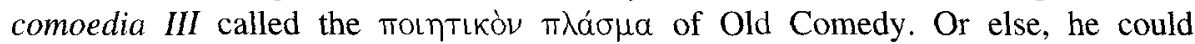

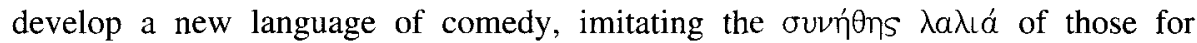
whom he now wrote, the common man, no matter if Athenian or not. 166 This new

${ }^{163}$ Cf. Dillon (1987) 176-80; note also the growing importance of Zeus Soter (David (1984) 24, Parker (1996) 238-41; in Aristophanes Zeus Soter is mentioned with increasing frequency from Thesmophoriazusae onward: Thesm. 1009, Ran. 738, 1433, Eccl. 79, 761, 1045, 1103, Plut. 877, 1175, 1186,1189 ) and of the 'private' healing god Asclepius (whom Aristophanes mentions only in Plut. 411, $621,636,640$, as well as Vesp. 123 where the god is still so much of an outsider that he is visited only after a try with a Corybantic ceremony).

164 Hansen (1991) 151.

${ }^{165}$ Cf. e.g. Gelzer (1970) 1505, Arnott (1972) 67, and especially Olson (1990) 232-3: 'on a practical level [Plutus] proposes only a (somewhat theoretically incoherent) withdrawal from common affairs'.

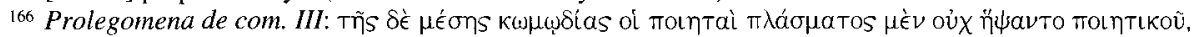

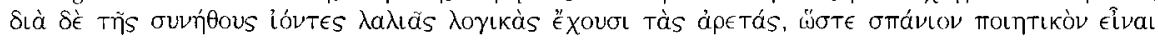

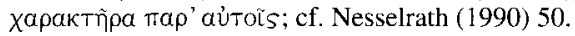


mimetic ${ }^{167}$ language so strongly shapes our Plutus and it has so much to do with the history of early fourth-century Athens that MacDowell must be wrong when he sees in our play nothing but a superficially revised version of the first Plutus of $408 \mathrm{BC} .168$

By way of conclusion, I would like to put forward one more thought arising from all this, but pointing far beyond the realm of comedy. As has been argued repeatedly in this paper, the four years that separate Ecclesiazusae and Plutus are no sufficient time-span to explain the linguistic gaps between the two fourth-century plays solely by reference to natural language development. If we account for this gap, as I suggest, with Aristophanes' conscious decision to write no longer in the polis-oriented, traditional style of Old Comedy, but in a new 'popular' way, ${ }^{169}$ we discover here for the first time an awareness of one great issue that came to threaten and enrich Greek literature until this day: diglossia. The observation that Aristophanes made up his mind between a 'pure' language respecting the established norms of the genre and a language imitating how people really spoke can also be formulated in Greek terms - and then anachronistically reads as follows: Aristophanes wrote his second Plutus not in

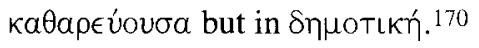

SEMINAR FÜR KLASSISCHE PHILOLOGIE, BASEL

ANDREAS WILLI

${ }^{167}$ Parodic disruptions are rare in Plutus (for a list of paratragic passages see Rau (1967) 207-9). For instance, the paratragic potential of the initial motif of a fatal encounter ordained by an oracle (as in Euripides' Ion) is not fully exploited; cf. Rau (1967) 160-1 and Silk (2000) 25: 'granted that the slave is to some degree talking the language of tragedy, his talk is still broadly "in character"' and we 'recognize a consistent type: a grumbling, honest, street-wise servant'. The rarity of integrated choral pieces and topical allusions produces 'a more coherent and unified work of art in which the dramatic illusion [is] more consistently maintained' (Dillon (1987) 174-5).

${ }_{168}$ Cf. MacDowell (1995) 324-7; for a refutation on non-linguistic grounds see Sommerstein (2001) 31-3. Van Leeuwen (1904) i-xxiv and Hertel (1969) 28-32 deny the existence of the earlier Plutus altogether.

${ }^{169}$ Of course Aristophanes need not have been the first to make such a decision: cf. e.g. Silk (2000) 51-2 on Middle Comedy elements in Crates and Pherecrates.

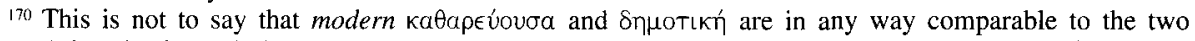

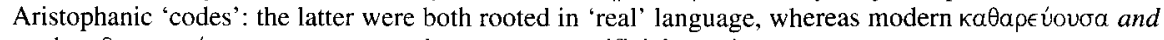
modern $\delta \eta \mu о т \iota k i ́$ are, to a greater or lesser extent, artificial creations. 


\section{REFERENCES}

Aerts, W. J. (1965) Periphrastica: an investigation into the use of $\epsilon \overline{i \nu}$ at and $\epsilon_{\chi \in \iota \nu}$ as auxiliaries or pseudoauxiliaries in Greek from Homer up to the present day, Amsterdam.

Allen, W. S. (1987) Vox graeca: a guide to the pronunciation of classical Greek (3rd edn.), Cambridge.

Amiguès, S. (1977) Les subordonnées finales par önws en attique classique, Études et commentaires 89 , Paris.

Arnott, W. G. (1972) 'From Aristophanes to Menander', $G \& R$ 19, 65-80.

Bain, D. (1984) 'Female speech in Menander', Antichthon 18, 24-42.

Bers, V. (1984) Greek poetic syntax in the classical age, Yale Classical Monographs 5, New Haven and London.

Birklein, F. (1888) Entwickelungsgeschichte des substantivierten Infinitivs, Beiträge zur historischen Syntax der griechischen Sprache 3.1, Würzburg.

Björck, G. (1940) ${ }^{\top} H \nu \delta ı$ Sá $\sigma \kappa \omega \nu$. Die periphrastischen Konstruktionen im Griechischen, Uppsala and Leipzig.

(1950) Das Alpha impurum und die tragische Kunstsprache. Attische Wort- und Stilstudien, Uppsala, Wiesbaden, and Leipzig.

Bowie, A. M. (1993) Aristophanes: myth, ritual and comedy, Cambridge.

Buck, C. D., and Petersen, W. (1944) A reverse index of Greek nouns and adjectives arranged by terminations with brief historical introductions, Chicago.

Chantraine, P. (1933) La formation des noms en grec ancien, Collection linguistique 38, Paris.

(1968-80) Dictionnaire étymologique de la langue grecque. Histoire des mots, Paris.

Coseriu, E. (1975) 'Der periphrastische Verbalaspekt im Altgriechischen', Glotta 53, 1-25.

Coulon, V. (1908) Quaestiones criticae in Aristophanis fabulas, Strasburg.

Croft, W. (1990) Typology and universals, Cambridge.

Cuny, A. (1906) Le nombre duel en grec, Paris.

David, E. (1984) Aristophanes and Athenian society of the early fourth century B.C., Leiden.

Debrunner, A. (1917) Griechische Wortbildungslehre, Heidelberg.

Denniston, J. D. (1954) The Greek particles (2nd edn.), Oxford.

Dietrich, W. (1973) 'Der periphrastische Verbalaspekt im Griechischen und Lateinischen', Glotta 51, $188-228$.

Dillon, M. J. (1985) 'Aristophanes Ploutos: comedy in transition', $\mathrm{PhD}$ thesis, Yale.

(1987) 'Topicality in Aristophanes' Ploutos', CA 6, 155-83.

Dover, K. J. (1970) 'Lo stile di Aristofane', QUCC 9, 7-23 (English tr. in K. J. Dover, Greek and the Greeks: collected papers, I: language, poetry, drama, Oxford and New York, 1987, 224-36).

(1972) Aristophanic comedy, Berkeley and Los Angeles.

(1974) Greek popular morality in the time of Plato and Aristotle, Oxford.

(1997) The evolution of Greek prose style, Oxford.

(2002) 'Some evaluative terms in Aristophanes', in A. Willi (ed.) The language of Greek comedy, Oxford, $85-97$.

Duhoux, Y. (1987) 'Le vocalisme des inscriptions attiques: une question de méthodes', Verbum 10,179-98.

Ehrenberg, V. (1951) The people of Aristophanes: a sociology of Old Attic Comedy, Oxford.

(1968) Aristophanes und das Volk von Athen. Eine Soziologie der altattischen Komödie, tr. G. Felten, Zurich.

Flashar, H. (1975) 'Zur Eigenart des aristophanischen Spätwerks', in H.-J. Newiger (ed.) Aristophanes und die Alte Komödie, Darmstadt, 405-34 (repr. from Poetica 1, 1967, 154-75; English tr. in E. Segal (ed.) Oxford readings in Aristophanes, Oxford and New York, 1996, 314-28).

Frisk, H. (1960-72) Griechisches etymologisches Wörterbuch, Heidelberg.

Gelzer, T. (1970) 'Aristophanes 12', RE Suppl. 12, 1392-1569.

Gignac, F. T. (1976) A grammar of the Greek papyri of the Roman and Byzantine periods, I: phonology, Milan. 
Hale, W. G. (1893) "Extended" and "remote" deliberatives in Greek', TAPA 24, 156-205.

Hansen, M. H. (1991) The Athenian democracy in the age of Demosthenes: structures, principles, and ideology, Oxford and Cambridge, Mass.

Headlam, W. (1922) Herodas: the mimes and fragments (ed. by A. D. Knox), Cambridge.

Heberlein, F. (1980) Pluthygieia. Zur Gegenwelt bei Aristophanes, Frankfurt am Main.

(1981) 'Zur Ironie im "Plutos" des Aristophanes', WJA n.s. 7, 27-49.

Henderson, J. (1987) Aristophanes: Lysistrata, ed. with introduction and commentary, Oxford.

(1991) The maculate muse: obscene language in Attic comedy (2nd edn.), New York and Oxford.

Hertel, G. (1969) Die Allegorie von Reichtum und Armut. Ein aristophanisches Motiv und seine Abwandlungen in der abendländischen Literatur, Erlanger Beiträge zur Sprach- und Kunstwissenschaft 33, Nuremberg.

Holzinger, K. (1940) Kritisch-exegetischer Kommentar zu Aristophanes' Plutos, Vienna and Leipzig.

Humbert, J. (1930) La disparition du datifen grec ( $d u \mathrm{I}^{e r}$ au $X^{e}$ siècle), Collection linguistique 33, Paris.

Hunter, R. L. (1985) The New Comedy of Greece and Rome, Cambridge.

Konstan, D. (1995) Greek comedy and ideology, New York and Oxford.

Kuhlmann, P. (1997/8) 'Eis als Indefinitpronomen im Griechischen in diachroner Sicht', Glotta 74, 76-93.

Kühner, R. (1890-2) Ausführliche Grammatik der griechischen Sprache, 1. Teil: Elementar- und Formenlehre (3rd edn. by F. Blass), Hanover.

Landfester, M. (1979) 'Geschichte der griechischen Komödie', in G. A. Seeck (ed.) Das griechische Drama, Darmstadt, 354-400.

La Roche, J. (1893) Beiträge zur griechischen Grammatik: Erstes Heft, Leipzig.

Lautensach, O. (1917) 'Grammatische Studien zu den attischen Tragikern und Komikern: Optativ [und Imperativ]', Glotta 8, 168-96.

(1921) 'Grammatische Studien zu den attischen Tragikern und Komikern: Infinitive und Partizipien', Philologus 77, 46-76 and 228-55.

Lévy, E. (1997) 'Richesse et pauvreté dans le Ploutos', Ktèma 22, 201-12.

López Eire, A. (1991) Ático, koiné y aticismo. Estudios sobre Aristófanes y Libanio, Murcia.

(1993) 'De l'attique à la koiné', in C. Brixhe (ed.) La koiné grecque antique, I: une langue introuvable? Études anciennes 10, Nancy, 41-57.

(1996) 'L'influence de l'ionien-attique sur les autres dialectes épigraphiques et l'origine de la koiné', in C.

Brixhe (ed.) La koiné grecque antique, II: la concurrence, Études anciennes 14, Nancy and Paris, 7-42.

Lyons, J. (1977) Semantics, 2 vols., Cambridge.

MacDowell, D. M. (1971) Aristophanes: Wasps, ed. with introduction and commentary, Oxford.

(1978) The law in classical Athens, London.

(1995) Aristophanes and Athens: an introduction to the plays, Oxford.

McGlew, J. (1997) 'After irony: Aristophanes' Wealth and its modern interpreters', AJP 118, 35-53.

Mayser, E. (1970) Grammatik der griechischen Papyri aus der Ptolemäerzeit mit Einschluss der gleichzeitigen Ostraka und der in Ägypten verfassten Inschriften. I: Laut- und Wortlehre, I. Teil: Einleitung und Lautlehre (2nd edn. by H. Schmoll), Berlin.

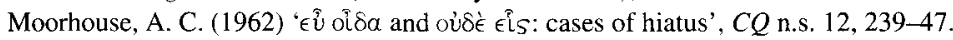

Nesselrath, H.-G. (1990) Die attische Mittlere Komödie. Ihre Stellung in der antiken Literaturkritik und Literaturgeschichte, Berlin and New York.

Newiger, H.-J. (1957) Metapher und Allegorie. Studien zu Aristophanes, Munich.

Olson, S. D. (1989) 'Cario and the new world of Aristophanes' Plutus', TAPA 119, 193-9.

(1990) 'Economics and ideology in Aristophanes' Wealth', HSP 93, 223-42.

Palmer, F. R. (1986) Mood and modality, Cambridge.

Parker, R. (1996) Athenian religion: a history, Oxford.

Pearson, A. C. (1917) The fragments of Sophocles, vol. 3, Cambridge.

Peppler, C. W. (1910) 'The termination -kós, as used by Aristophanes for comic effect', AJP 31, 428-44.

(1918) 'Comic terminations in Aristophanes: part IV', AJP 39, 173-83. 
Perusino, F. (1987) Dalla commedia antica alla commedia di mezzo: tre studi su Aristofane, Urbino.

Poultney, J. W. (1963) 'Studies in the syntax of Attic comedy', AJP 84, 359-76.

Radt, S. L. (1976) 'Zu Aristophanes' Plutos', Mnemosyne 4th ser. 29, 254-67.

Rau, P. (1967) Paratragodia. Untersuchung einer komischen Form des Aristophanes, Zetemata 45, Munich.

Rutherford, W. G. (1903) 'Aristophanes, Knights 414: a neglected idiom', CR 17, 249.

Schade, J. (1908) De correptione Attica, Diss. Greifswald.

Schmidt, J. H. H. (1876) Synonymik der griechischen Sprache, l. Band, Leipzig.

Schwab, O. (1895) Historische Syntax der griechischen Comparation in der klassischen Litteratur. 3. Heft: Des besonderen Teiles III. \& IV. Abschnitt, Beiträge zur historischen Syntax der griechischen Sprache $4.3=13$, Würzburg.

Schwyzer, E. (1939) Griechische Grammatik, I: Allgemeiner Teil, Lautlehre, Wortbildung, Flexion, Handbuch der Altertumswissenschaft 2.1.1, Munich.

(1940) 'Syntaktische Archaismen des Attischen', Abhandlungen der Preussischen Akademie der Wissenschaften, philosophisch-historische Klasse Nr. 7.

Schwyzer, E., and Debrunner, A. (1950) Griechische Grammatik. II: Syntax und syntaktische Stilistik, Handbuch der Altertumswissenschaft 2.1.2, Munich.

Sfyroeras, P. (1995) 'What wealth has to do with Dionysus: from economy to poetics in Aristophanes' Plutus', GRBS 36, 231-61.

Silk, M. S. (2000) Aristophanes and the definition of comedy, Oxford.

Slotty, F. (1915) Der Gebrauch des Konjunktivs und Optativs in den griechischen Dialekten, I: Der Hauptsatz, Forschungen zur griechischen und lateinischen Grammatik 3, Göttingen.

Smyth, H. W. (1894) The sounds and inflections of the Greek dialects: Ionic, Oxford.

Sobolewski, S. (1890) De praepositionum usu Aristophaneo, Moscow.

Sommerstein, A. H. (1984) 'Aristophanes and the demon Poverty', $C Q$ n.s. 34, 314-33.

(2001) Aristophanes: Wealth, ed. with tr. and commentary, Warminster.

Stevens, P. T. (1976) Colloquial expressions in Euripides, Hermes Einzelschriften 38, Wiesbaden.

Süss, W. (1954) 'Scheinbare und wirkliche Inkongruenzen in den Dramen des Aristophanes (Schluss)', RhM n.s. 97, 289-313.

Sütterlin, L. (1891) Zur Geschichte der Verba denominativa im Altgriechischen, I: Die Verba denominativa auf $-\alpha \omega \omega,-\epsilon \omega,-\delta \omega$, Strasburg.

Teodorsson, S.-T. (1987) 'Boeotian and Attic: vowel development related?', Verbum 10, 199-209.

Threatte, L. (1980) The grammar of Attic inscriptions, I: Phonology. Berlin and New York.

(1996) The grammar of Attic inscriptions, II: Morphology, Berlin and New York.

Thumb, A. (1901) Die griechische Sprache im Zeitalter des Hellenismus. Beiträge zur Geschichte und Beurteilung der Kouví, Strasburg.

(1932) Handbuch der griechischen Dialekte: Erster Teil (2nd edn. by E. Kieckers), Heidelberg.

(1959) Handbuch der griechischen Dialekte: Zweiter Teil (2nd edn. by A. Scherer), Heidelberg.

Todd, O. J. (1932) Index Aristophaneus, Cambridge, Mass.

Ussher, R. G. (1973) Aristophanes: Ecclesiazusae, ed. with introduction and commentary, Oxford.

Leeuwen, J. van (1904) Aristophanis Plutus cum prolegomenis et commentariis, Leiden.

Vogt-Spira, G. (1992) Dramaturgie des Zufalls. Tyche und Handeln in der Komödie Menanders, Zetemata 88 , Munich.

Wackernagel, J. (1887) 'Miszellen zur griechischen Grammatik', $K Z$ 28, 109-45 (repr in J. Wackernagel, Kleine Schriften, Göttingen, 1953, 1.591-627).

(1889) 'Das Dehnungsgesetz der griechischen Composita', Rektoratsprogramm Basel, 1-65 (repr in J. Wackernagel, Kleine Schriften, Göttingen, 1953, 2.897.961).

(1893) 'Beiträge zur Lehre vom griechischen Akzent', Rektoratsprogramm Basel, 3-38 (repr in J. Wackernagel, Kleine Schriften, Göttingen, 1953, 2.1072-1107).

(1907) 'Hellenistica', Programm Göttingen, 3-27 (repr in J. Wackernagel, Kleine Schriften, Göttingen, 1953, 2.1034-58). 
(1926) Vorlesungen über Syntax mit besonderer Berïcksichtigung von Griechisch, Lateinisch und Deutsch: Erste Reihe (2nd edn.), Basle.

(1928) Vorlesungen über Syntax mit besonderer Berücksichtigung von Griechisch, Lateinisch und Deutsch: Zweite Reihe (2nd edn.), Basle.

Weber, P. (1884) Entwickelungsgeschichte der Absichtssätze, 1: Von Homer bis zur attischen Prosa, Würzburg.

(1885) Entwickelungsgeschichte der Absichtssätze, II: Die attische Prosa und Schlussergebnisse, Würzburg.

Webster, T. B. L. (1970) Studies in later Greek comedy (2nd edn.), Manchester.

Wilamowitz-Moellendorff, U. von (1909) Euripides Herakles (2nd edn.), Berlin.

Willi, A. (2002) 'The language of Greek comedy: introduction and bibliographical sketch', in A. Willi (ed.)

The language of Greek comedy, Oxford, 1-32.

(2003) The languages of Aristophanes: aspects of linguistic variation in classical Attic Greek, Oxford. Zuntz, G. (1971) Persephone: three essays on religion and thought in Magna Graecia, Oxford. 